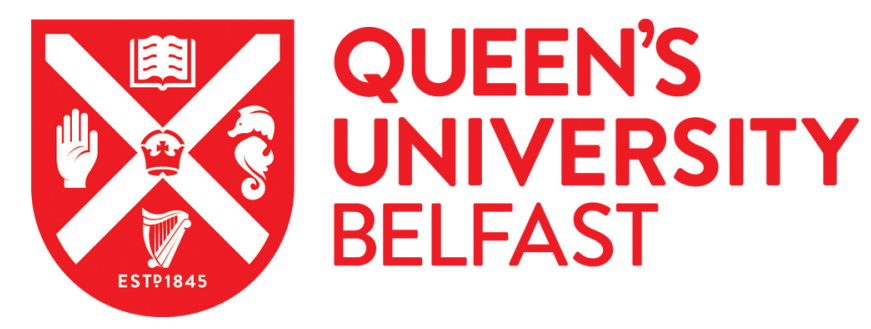

\title{
This Time is Different: Causes and Consequences of British Banking Instability over the Long Run
}

Campbell, G., Coyle, C., \& Turner, J. D. (2016). This Time is Different: Causes and Consequences of British Banking Instability over the Long Run. Journal of Financial Stability, 27, 74-94.

https://doi.org/10.1016/j.jfs.2016.09.007

Published in:

Journal of Financial Stability

Document Version:

Peer reviewed version

Queen's University Belfast - Research Portal:

Link to publication record in Queen's University Belfast Research Portal

\begin{abstract}
Publisher rights
(c) Elsevier Ltd.

This manuscript version is made available under the CC-BY-NC-ND 4.0 license http://creativecommons.org/licenses/by-nc-nd/4.0/ which permits distribution and reproduction for non-commercial purposes, provided the author and source are cited.
\end{abstract}

\section{General rights}

Copyright for the publications made accessible via the Queen's University Belfast Research Portal is retained by the author(s) and / or other copyright owners and it is a condition of accessing these publications that users recognise and abide by the legal requirements associated with these rights.

Take down policy

The Research Portal is Queen's institutional repository that provides access to Queen's research output. Every effort has been made to ensure that content in the Research Portal does not infringe any person's rights, or applicable UK laws. If you discover content in the Research Portal that you believe breaches copyright or violates any law, please contact openaccess@qub.ac.uk. 


\title{
This Time is Different: Causes and Consequences of British Banking Instability over the Long Run
}

\author{
Gareth Campbell, Christopher Coyle*, John D. Turner \\ Queen's Management School, Queen's University Belfast, Riddel Hall, 185 Stranmillis Road, \\ BT9 5EE, N. Ireland
}

\begin{abstract}
This paper addresses three questions: (1) How severe were the episodes of banking instability experienced by the UK over the past two centuries? (2) What have been the macroeconomic indicators of UK banking instability? and (3) What have been the consequences of UK banking instability for the cost of credit? Using a unique dataset of bank share prices from 1830 to 2010 to assess the stability of the UK banking system, we find that banking instability has grown more severe since the 1970s. We also find that interest rates, inflation, lending growth, and equity prices are consistent macroeconomic indicators of UK banking instability over the long run. Furthermore, utilising a unique dataset of corporate-bond yields for the period 1860 to 2010, we find that there is a significant long-run relationship between banking instability and the creditrisk premium faced by businesses.
\end{abstract}

JEL classification: G10, G21, N13, N14, N23, N24

Keywords: Banking crises, Cost of credit, Financial instability

\footnotetext{
* Corresponding author: Tel: +44 (0) 2890974518

E-mail address: c.coyle@ qub.ac.uk (C. Coyle)
}

We are grateful to two anonymous referees for valuable comments. Thanks to Graeme Acheson, Mark Billings, Jagjit Chadha, David Chambers, William Janeway, Joost Jonker, Anthony Hotson, Donal McKillop, Ranald Michie, Duncan Needham and to seminar and conference participants at Cambridge University, Queen's University Belfast, the Scottish Economic Society conference in Perth, the Money, Macro and Finance conference in Durham and the Economic History Society conference in Warwick, for their comments. Coyle acknowledges financial support from the Department of Education and Learning. 


\section{Introduction}

The severity of the banking crisis of 2007-8, combined with the fact that they are infrequent events, has led scholars to look increasingly to history in order to understand better the potential causes and consequences of banking instability (Reinhart and Rogoff, 2009; Grossman 2010; Jordà et al., 2011; Schularick and Taylor, 2012). However, such studies use a narrative approach in determining whether a crisis has occurred or not, making it difficult to differentiate between different levels of instability. This approach is also subjective in that there is divergence of opinion over what constitutes a banking crisis. As a consequence, time-series analysis of the causes and consequences of banking instability is somewhat limited. One way of overcoming these difficulties is to use bank stock prices to measure instability (Reinhart and Rogoff, 2009, p. 8). In this paper, we adopt this approach by constructing a dataset of monthly British bank share prices covering a 181-year period, in order to develop a precise and continuous measure of UK banking instability over the long run.

Our share-price dataset is used to address two key questions: (1) What are the macroeconomic indicators of instability over the long run? (2) What effect does banking instability have on the cost of credit? We examine potential causes and consequences of banking instability using Granger causality tests based on vector autoregression (VAR) models. Firstly, we test which macroeconomic variables consistently act as good predictors of banking instability over our sample period. Secondly, we examine if there is a long-run historical relationship between banking instability and the credit-risk premium faced by firms. In order to measure the credit-risk premium for the UK, a new proxy is developed, using a hand-collected dataset of UK corporate bond yields. This, to the best of our knowledge, is the first long-run time-series test of the hypothesis that banking instability affects the cost of credit.

Using our bank-share-price dataset, we find that although the British banking system has faced episodic bouts of instability at various points throughout the past two centuries, instability 
increases significantly in the final quarter of the twentieth century. This increase in instability culminated in the 2007-8 banking crisis, which according to our share-price measure is on a totally different scale to all previous episodes of banking instability in the UK. Notably, several of the UK banking crises identified as such by Reinhart and Rogoff (2009) do not manifest themselves in our data. Furthermore, using our measure, the classic nineteenth-century crises do not appear to be as severe for the banking system as standard narratives would suggest. However, this is not to say that these crises did not affect other parts of the financial system.

In terms of leading macroeconomic indicators of crises, our results imply that interest rates, inflation, credit growth, and equity prices have significant predictive power for UK banking instability over the long run. This suggests that the stability of these factors should be an important policy goal.

Our study also provides the first evidence of a significant predictive relationship between banking instability and the credit risk premium over the long run. Furthermore, our long-run evidence suggests that the increase in the cost of credit following banking instability appears to be more severe and prolonged for smaller and more risky firms. This highlights the importance of maintaining channels of credit to small businesses following banking instability. A caveat to these results is that we use bond yields as a proxy for the cost of credit. In most cases, credit obtained through the bond market or from banks should be close substitutes, but it is possible that this is not always the situation and our measure of the cost of credit may be imperfect.

The findings of this paper contribute to the literature on banking stability in several ways. First, it augments the literature on the frequency, severity and measurement of financial crises (Bordo et al., 2001; IMF, 1998; Caprio and Klingbiel, 1996; Reinhart and Rogoff, 2009; Schularick and Taylor, 2012; Taylor, 2012). It does so by developing a new measure of banking instability, which helps provide more of an idea of the scale of banking crises than the 
commonly-used narrative approach. This approach suggests, that at least in the case of the UK, the extant literature overestimates the occurrence of severe banking crises.

Second, the paper contributes to the literature on the macroeconomic factors that make banking crises more likely to occur (Hardy and Pazarbasioglu, 1998; Demirgüç-Kunt and Detragiache, 1998a; 1998b; 1999; Kaminsky and Reinhart, 1999; Bergman and Hansen, 2002; Van den End, 2006, Davis and Karim, 2008; Schularick and Taylor 2012, Bordo et al. 2003). In particular, it does so by showing that over the long run, credit growth has been an important contributor to UK banking instability. However, unlike Jordà et al. (2014), we find little evidence that house prices contribute to banking instability over the long run. Although the housing boom was major contributor to the 2008 financial crisis, it was not an important contributor to most previous crises.

Finally, this paper augments the literature which highlights the link between banking instability and the credit-risk premium faced by firms. It is the first long-run analysis of how banking instability affects the cost of credit, whereas most previous literature has focused on particular crisis episodes (Bernanke, 1983; Ding, Domac, and Ferri, 1998; Borensztein and Lee, 2000; Hall, 2010; Krishnamurthy, 2010). The only other long-run view of crises and credit is Bordo and Haubrich (2010), who trace the effect of credit distress events on output in the United States from 1875 onwards. Similar to the findings of this extant literature, the long-run evidence from the UK suggests that banking instability is followed by an increase in the cost of credit intermediation.

This paper is structured as follows. In section two, our hypotheses on the leading macroeconomic indicators of banking instability and the effect of banking instability on the cost of credit are developed. Section three discusses our data sources and methodology. Section four examines the evolution of British banking instability over the last two centuries. Section five analyses fluctuations in key macroeconomic variables around specific and noteworthy banking 
crises and then presents Granger causality tests for the macroeconomic indicators of UK banking instability. Section six analyses the consequences of banking instability for the cost of credit to business. Section seven then summarises the main findings and concludes.

\section{Banking Instability: Theory and Hypotheses}

\subsection{Macroeconomic indicators of banking instability}

Banking instability can develop from the decisions made by banks in the peaks and troughs of the business cycle. During economic upswings, banks may underestimate the problems associated with asymmetric information, which may lead to over-lending and increased lending to risky projects. In such an environment, banks are susceptible to a sudden macroeconomic shock, which may decrease the ability of borrowers to repay. Thus, this potential 'boom and bust' nature of bank activities may lead to increased instability (Minsky, 1977; Gavin and Hausmann, 1996, p. 13; Grossman, 2010, p. 74; Reinhart and Rogoff 2009, p. xxvii). Notably, many studies have found that rapid credit growth appears to be consistently associated with systemic banking crises (McKinnon and Pill, 1997; Kaminsky and Reinhart, 1999; Eichengreen and Arteta, 2000; Allen and Gale, 2000; Logan, 2001; Hardy and Pazarbasioglu, 1998; Gourinchas, Valdes, and Landerretche, 2001; Wong et al., 2010). In particular, cycles of over lending that drive or are accompanied by booms in equity and housing markets have been found to increase banking instability (Borio and Lowe, 2002; González-Hermosillo, 1999; Jordà, Schularick and Taylor, 2011; Reinhart and Rogoff, 2009, pp.158-160; Reinhart and Rogoff, 2008; Schularick and Taylor, 2012).

In this paper, we hypothesise that credit growth and asset prices are associated with banking instability. In addition, changes in nominal interest rates and inflation can stimulate credit booms and sharp changes in asset prices (Alchian and Kessel, 1962), and may therefore be associated with credit booms. Flamini and Milas (2015) identify a positive relationship between 
interest rate volatility and financial instability in the UK, US and Sweden. As the UK banking system has never heavily relied on foreign-currency-denominated debt, exchange rate movements should not result in increased costs of servicing such debt (Kaufman 1999, pp.1516). Notably, Eichengreen and Arteta (2000) find that currency problems are not an important cause of banking crises.

It is possible that macroeconomic triggers are not endogenous to the banking system. For example, Gavin and Hausmann (1996, pp. 27-28) use the analogy of a chain to emphasise the macroeconomic roots of banking crises. When macroeconomic forces place strain on the banking system, the weakest banks are the ones most likely to fail, but it is the macroeconomic tension, as much as the weakness of individual banks, that causes the failures. In other words, macroeconomic shocks which are exogenous to the banking system make it unstable. For example, increases in the nominal interest rate may cause problems as borrowers may face difficulties in servicing their debt, which potentially increases the number of loan defaults and increases the probability of the bank being in financial distress.

\subsection{Banking instability and the cost of credit}

The economic consequences of instability in the banking system are potentially severe and far reaching (Bernanke, 1983; Dell'Ariccia et al., 2007; Demirgüç-Kunt et al., 2006; Hoggarth et al, 2002; Laeven and Valencia, 2010; Laeven, 2011; Deaton, 2012). Although there is little dispute about the economic costs associated with banking crises, the channels through which problems in the banking sector affect economic output have long been queried. Friedman and Schwartz (1963) argue that banking difficulties can exacerbate the economic situation through the monetary channel due to a rapid decrease in the money supply and money multiplier. Another channel is the extent to which output is constrained by the effect that banking instability has on the availability and cost of credit. 
Disruption of the banking system reduces the ability of banks to alleviate the asymmetric information problem effectively and efficiently (Mishkin, 1991; Bernanke and Gertler, 1989, 1990; Bernanke et al., 1999; Holmstrom and Tirole, 1997; Kiyotaki and Moore, 1997; Christiano et al., 2010). In addition, periods of distress may be accompanied by shocks to asset prices, which erode a borrower's collateral-to-debt burden (Bernanke 1983; Bernanke et al., 1996). Banks, operating in an environment of increased uncertainty, face a dilemma of whether to reject those seeking credit, charge higher premiums, or a combination of both, as they attempt to recapitalise or reduce exposure to risky assets. This results in a higher cost of credit intermediation or credit-risk premium, particularly for small- and medium-sized borrowers (Bernanke, 1983; Bernanke and Gertler, 1995; Calomiris and Mason, 2003).

As banks have an advantage in assessment of credit risk through their developed expertise in screening and monitoring, alternative channels of credit are likely to have a similar increased cost of credit intermediation (Bernanke 1983, p.264). In bond markets, credit-related components of yield spreads will increase, reflecting assessments of default risk, but also noncredit components, such as increases in illiquidity of credit markets (Churm and Webber, 2007). Notably, Altman et al. (2010) highlight the causal link running from bank loan returns to bond returns during periods of distress.

In this paper, we hypothesise that banking instability results in an increase in the creditrisk premium on the corporate bond market faced by firms and that this increase is particularly severe for smaller firms. Although our focus in this paper is on the credit channel, we also test for the presence of a monetary channel by analysing the effect of banking instability on the money supply.

\section{Data and Methodology}


Studies on banking crises over the long run generally use a narrative and binary approach in determining whether a crisis has occurred or not (e.g., Goodhart and Delargy, 1998; Bordo et al., 2001; Grossman, 2010; Reinhart and Rogoff, 2009; Valencia and Laeven, 2012; Schularick and Taylor, 2012). Reinhart and Rogoff (2009), for example, define a banking crisis as bank runs that lead to closure, merging or a public-sector takeover of one or more financial institutions or the closure, merging, takeover or public-sector assistance of an important financial institution. Following this approach, we could measure banking stability over the long run using bank failure data. We eschew this approach because bank failures do not mean that a banking system is unstable and may actually promote banking stability, as was the case in the UK in the nineteenth century (Baker and Collins, 1999). In addition, the Reinhart and Rogoff (2009) definition includes financial institutions that may not be creating deposits or intermediating credit. In addition, in the case of the UK, there are long periods of time whereby we cannot be sure if Bank of England assistance was secretly provided or if distressed mergers occurred or were arranged.

Consequently, in this paper, in order to assess quantitatively the long-run time-series variation in British banking instability, a new data-set of monthly share prices of British commercial banks for the period 1830 to 2010 is constructed. The reasoning here is that problems or uncertainty surrounding the banking sector, no matter the source, are likely to be reflected in bank share prices, assuming that markets are relatively efficient.

The data-set starts in 1830 because prior to this, there were very few joint-stock commercial banks since banking incorporation law had only been liberalised in the mid-1820s. Foreign or colonial banks, which are registered in London, are excluded as they generally conducted the majority of their business outside of the UK. 
Monthly share price data were hand-collected for all London banks from 1834 onwards, for all Scottish banks from 1830 onwards, and for all Irish banks for 1830-1921. ${ }^{1}$ English provincial banks (i.e., banks located outside a 65-mile radius of London) were relatively small and their shares traded infrequently until the 1870s. We have share price data for the provincial banks traded on the London Stock Exchange up until 1868 and share price data for all provincial banks from 1869 onwards. Appendix Table 1 provides details on our data sources. Bank returns are equally-weighted and adjusted for events such as changes in capitalisation, stock splits and reverse stock splits. Our preference for equally-weighted returns arises from the concept that problems at smaller banks may highlight systemic issues. However, to ensure that our results are not being driven by our weighting methodology, we collected data on market capitalisation (see Appendix Table 1 for sources) to construct a value-weighted series. As can be seen from Fig. 1, there is little difference between the equally- and value-weighted series - the correlation between the two series is 96.1 per cent. Our results are robust to using the value-weighted series.

The absolute value of average bank returns, a non-parametric measure of volatility, is used as the baseline measure of banking instability. Absolute returns have been shown to be a simple and accurate measure of volatility in time series data (Ding, Granger and Engel, 1993; Granger and Sin, 2000; Forsberg and Ghysels, 2007). Absolute returns are also more robust than other measures of volatility in the presence of large movements, such as booms and crashes (Davidian and Carroll, 1987; Cotter, 2004). Robustness tests are run using drawdown of bank returns, measured by the change in an index of bank returns from its previous historical peak, nominal bank returns, and volatility of bank returns, measured by the non-overlapping annual standard deviation of average monthly returns. ${ }^{2}$

\footnotetext{
${ }^{1}$ Since joint-stock banks could not establish in London until 1833 due to the Bank of England's charter, the earliest share price for a London bank is August 1834.

${ }^{2}$ For example, if we have a new peak in the index of bank returns in 2000 at 100, and the index closed at 80 in 2001 , 60 in 2002 and 105 in 2003, the drawdown each year would be $-20 \%,-40 \%$ and $5 \%$ respectively.
} 
As a key objective of this paper is to test potential macroeconomic indicators of banking instability as well as the effect of banking stability on the cost of credit for business over the long run, data for several other variables were collected. ${ }^{3}$ First, potential macroeconomic indicators were collected i.e., UK equity returns, GDP, dollar exchange rates, interest rates, inflation rates, commodity prices (proxied by wheat prices), net public debt, M3 money supply data, house price data, and bank lending data (see Appendix Table 1 for data sources). ${ }^{4}$ Second, in order to test the relationship between banking instability and the cost of credit, we use the UK corporate bond yield differential over government bonds as a proxy for the cost of credit intermediation or the premium borrowers must pay for credit. The yield spread between government and corporate debt is a commonly used measure of changes in the cost of credit during specific periods of banking instability (Bernanke, 1983; Hall, 2010; Bordo and Haubrich, 2010), and is recognised by the Bank of England as a proxy for the spread on bank borrowing for larger businesses (Butt and Pugh, 2014). In the UK, bank and bond markets have acted as good substitutes for loan capital. Historically, when banks were reluctant to advance money to businesses, the corporate bond market was an important alternative source of capital for companies of all sizes. Equally, banks stepped in to offer finance following the decline in the UK corporate bond market in the 1970s (Coyle and Turner, 2013). Therefore, any increase in the cost of credit as the result of banking difficulties should also be reflected in the bond market. This is supported by the fact that the average annual corporate bond yield in our sample has a correlation of 90 per cent with the bank bill rate between 1870 and 2005, which is the rate on short-term debt instruments in which banks dealt. ${ }^{5}$

\footnotetext{
${ }^{3}$ We collect data on annual basis, as a number of the variables we use are not available at a greater frequency than annual for the full sample, including a number of hand collected variables.

${ }^{4}$ While changes in bank capital ratios may be an important predictor of changes in bank instability, this is difficult to measure accurately over the long run due to the presence of unlimited liability, reserve liability, uncalled capital, and hidden reserves. Therefore, the capitalisation of banks is not a focus of this paper.

${ }^{5}$ The bank bill rate refers to the prime bank bill rate for 1870-1982 from Capie and Webber (2010), and the eligible bank bill rate for 1983-2005, available from the Bank of England Interactive Database. Banks ceased accepting eligible bank bills in 2005 .
} 
Our corporate bond dataset consists of hand-collected annual data, running from 1860, the first date for which we can find published data on UK corporate bonds, to 2010 (see Appendix Table 1 for data sources). ${ }^{6}$ Corporate bond yields are calculated from bonds issued by domestic UK companies. A company was considered to be a UK company if its corporate headquarters and the main market where its securities traded were in the UK and its main activities were based in the UK. ${ }^{7}$ Our corporate bond dataset contains 49,804 observations. The yields on the government debt market are based on Consol prices for the period 1860 to 1955 , and from 1955, a portfolio of high-coupon, long-dated bonds (see Appendix Table 1 for data sources).

Several studies have specifically used the yield differential between Baa corporate bonds and U.S government bonds when constructing a measure of the cost of credit (e.g., Bernanke, 1983; Mishkin, 2009; Bordo and Haubrich, 2010; Hall 2010). As there is no equivalent 'Baa' rating system for our UK sample, we use the average annual yield differential for our full sample of corporate bonds over UK government bonds. However, we also subdivide our corporate bond risk premium into two equal subsets for each year in the sample - one containing firms with above median yields and one containing firms with below median yields. This enables us to assess whether banking instability has a different effect on the credit-risk premium of firms in different risk grades.

As can be seen for Table 1, which contains summary statistics of our key variables, bank returns are volatile, with a standard deviation of 20.32 per cent and a large range in annual returns. Several other variables appear similarly volatile. Money supply, commodity prices,

\footnotetext{
${ }^{6}$ All financial companies that issued bonds are excluded as these firms, for a large part of the sample period, were mainly financial trusts which issued bonds with the aim of investing the bulk of the proceeds in the equities and bonds of foreign companies (Jefferys 1977, p.262).

${ }^{7}$ The criteria used to determine whether a firm was based in the UK or overseas was based on (a) the section in which it appears in the relevant stock-exchange yearbook (e.g., Foreign Railways), (b) the company's name (e.g., New Zealand and Australia Land Co. Ltd.), or (c) if the company had a head office in a foreign country of operation as well as one in the UK. This information was obtained from a combination of the Investor's Monthly Manual (1864-1930); Burdett's Official Intelligence (1882-98), the Stock Exchange Official Intelligence (1899-1933), and the Stock Exchange Yearbook (1934-2010).
} 
public debt growth, and equity returns all have standard deviations of 13 per cent or greater. Notably, the volatilities of each of the three risk premium variables are similar over the full sample period.

In order to test our hypotheses, multiple-dimension vector autoregression (VAR) models and Granger causality tests are used in order to determine if there is a statistically significant relationship between macroeconomic variables and banking instability and between banking instability and the credit-risk premium. As the variables concerned may simultaneously influence one another over the sample period and the exact structure of the underlying relationship of the multiple time series is unknown, VAR models are used to account for the dynamics of all variables. The multivariate VAR model is of the form:

$$
Y_{t}=\beta_{0}+\beta_{1} Y_{t-1}+\ldots . .+\beta_{m} Y_{t-m}=u_{t}
$$

where $Y_{\mathrm{t}}$ is a vector of all the macroeconomic and banking stability variables included in the system, $\beta_{0}$ is a vector of constants, $\beta_{1 \ldots} \beta_{\mathrm{m}}$ are matrices of coefficients of all the lagged variables, $m$ represents the number of lags of each variable, and $u_{i}$ is a set of error terms. The exact specification of the VAR model is discussed in greater detail in sections 5 and 6 .

\section{$<$ TABLE 1 HERE $>$}

\section{British Banking Stability Over the Long Run}

\subsection{Nineteenth-century crises}

From Figs. 1, 2 and 3, which contain our series of British bank returns and also highlight episodes defined by Reinhart and Rogoff (2009) as banking crises, we see that several years in which crises are said to have taken place during the nineteenth century show negative stock returns. In particular, the crises in 1847, 1857, 1866 and 1878 are associated with negative returns. However, as can be seen from Table 2, relative to the overall market, the fall in bank 
stocks during these four episodes were not particularly severe and very few bank stocks lost more than 20 per cent of their value. Notably, the banking crises in 1836-9 and 1890 are not associated with negative returns or volatility in the market for bank shares.

\section{$<$ FIGS. 1, 2, 3 \& TABLE 2 HERE>}

One possible reason as to why we do not find that these nineteenth-century crises are associated with large falls in bank stocks is that a lot of commercial banking was still performed by small private banks, particularly in the first half of the nineteenth century. However, the failure rate of private banks was never higher than 2.3 per cent during any of these crises (Turner, 2014, p. 53). Another possible reason is that there were not systemic problems during this era; rather the banking problems experienced in the nineteenth century were more idiosyncratic. Below we provide some context for each crisis which illustrates this point.

The banking problems of 1836-9 were chiefly manifested in the prominent failures of the Agricultural and Commercial Bank of Ireland and Northern and Central Bank of England. Unlike most of their counterparts, these two banks had expanded rapidly (particularly their branch network) following their establishment in 1834. They were also both riddled with unique governance problems.

During the 1847 crisis, several medium-sized banks in the north-east of England failed and several other English banks temporarily suspended payments. The 1847 crisis was in reality a commercial crisis accompanied by a money-market crisis, which was precipitated by the fear that the newly-established Bank Charter Act curtailed the ability of the Bank of England to act as a lender of last resort.

Following the arrival of news from the U.S. in the autumn of 1857 that railroad securities had fallen substantially and that there were numerous bank suspensions on the Atlantic coast, many British firms involved in trading with the U.S. failed, which placed pressure on their banks. Three important banks failed in this crisis - Liverpool Borough Bank, Western Bank of Scotland, 
and the Northumberland and Durham District Bank. Each of these three failures was idiosyncratic, with aggressive risk-taking, long-term accumulation (and hiding) of bad debts, and concentrated lending (Turner, 2014, pp. 77-78).

The 1866 crisis was largely precipitated by the failure of Overend, Gurney and Company, a discount house, which after accumulating large (but hidden) bad debts from the late 1850s onwards had converted to a limited-liability public company in 1865 . Several small banks as well as the Birmingham Banking Company, a large bank which was the most senior bank in the West Midlands, failed following the Overend Gurney collapse. In each of these cases of failure, there was clear mismanagement and in several instances there was concentrated lending, insider lending, and fraudulent accounting (Turner, 2014, pp.82-4).

The central event of the 1878 crisis was the failure of the City of Glasgow Bank Glasgow's premier bank, which had the third largest branch network in the UK. The $£ 5$ million deficit between its assets and liabilities was met by calls on its shareholders, the majority of whom were bankrupted by the action (Acheson and Turner, 2008). The City of Glasgow Bank had a very risky asset management strategy, concentrated loan portfolio, and directors who had engaged in fraud (for which several of them were subsequently incarcerated). Other banks, and in particular the Bank of England, had never trusted this bank (Clapham, 1944, vol. 2, p.309; Rait, 1930). The other major bank to fail in this crisis was the West of England and South Wales District Bank, and similar to the City of Glasgow Bank, it had concentrated loans, falsified accounts, and fraudulent attempts were made to conceal the bank's real position from its shareholders (Turner, 2014, p. 87).

At the time of its failure in 1890, Barings Brother and Co. was one of the most powerful merchant banks in Europe. During the 1880s, it had invested heavily in the emerging economies of Argentina and Uruguay. However, economic difficulties in these countries resulted in Barings suffering such large losses that it required a guarantee fund co-ordinated by the Bank of England 
and funded by major commercial banks to prevent its collapse. It is entirely possible that this action taken by the Bank of England, which was fully supported by the UK Treasury, prevented commercial banks from failing or their stock prices from falling (Collins and Baker, 2003, p.99). However, on closer inspection of Fig. 3, we do not see a fall in bank stocks in the month or months before the Bank of England's support arrangement was announced.

\subsection{Twentieth-century crises}

When we move into the twentieth century, we observe from Figs. 1, 2 and 3 that bank stocks became more volatile in the twentieth century compared to the nineteenth century, particularly in the second half of the twentieth century. This is consistent with studies indicating that financial instability has increased in the post Bretton Woods era (Bordo et al., 2001).

Notably, although bank stocks fell by nearly 25 per cent during the Great Depression (Fig. 1), they fell by less than the overall stock market. This is consistent with the view that Britain did not experience a banking crisis during this period (Grossman, 1994; Capie and Wood, 2012, p. 333).

Of the five twentieth-century crises identified by Reinhart and Rogoff (2009), only 1914 and 1974 are associated with negative returns on bank stocks. The breakdown of European capital markets and the foreign-exchange crisis in the summer of 1914 did not cause major instability in the banking sector as indicated by Fig. 1 and Table 2. Although capital markets were closed from July 1914 through the rest of 1914, bank stocks did not decline when the market reopened. However, the extension of the usual August Bank Holiday in 1914 by four days plus the issue of Treasury notes contributed to the easing of liquidity pressures faced by banks following the breakdown of the European markets (Sayers, 1976, Vol. 1, pp.74-6).

The negative returns on bank stocks in 1974 clearly stand out in Fig. 1. Secondary banks, which had raised funds on the newly-liberalised money markets and advanced them in the form of property and consumer finance loans, got into difficulties in late 1973 (Capie, 2010, pp.524- 
86; Reid, 1982). Commercial banks, coordinated by the Bank of England, provided liquidity support, and, as a result, the difficulties almost passed unnoticed (Reid, 1982, p. 200). Fig. 1 shows significant volatility during this period with large negative returns of -27.79 per cent in 1973 and -62.85 per cent in 1974 , indicating much greater instability than at any earlier stage in the sample. However, the large fall in bank stocks is quickly followed by a huge rebound in returns the following year (Fig. 1). While this may reflect the difficulties faced by the secondary banks in the UK, this pattern is also found in the overall equity market during this period, suggesting that bank shares were really influenced by other factors, including the 1973 Oil Crisis and extremely high inflation. When the returns of the overall equity market are taken into account, the excess returns on bank stocks are only -8.0 per cent (Table 2).

As can be seen from Fig. 1 and Table 2, there is little evidence of negative returns in 1984, 1991 and 1995. In fact, banks stocks outperform the overall stock market in each of these years. 1984 is classified as a banking crisis by Reinhart and Rogoff (2009) because of the failure of Johnson Matthey Bankers, a bullion dealer which had expanded into lending in the early 1980s. This bullion dealer was taken over by the Bank of England and the Bank co-ordinated a private-sector indemnity fund. These actions may have prevented a fall in bank stocks, but from Fig. 3, we see that in the month before the Bank's action, bank stock prices actually rose. The 1991 crisis is designated as such by Reinhart and Rogoff due to the collapse of the Bank of Credit and Commerce International, an international bank with operational headquarters in London. The 1995 crisis is designated as such following the collapse of Barings Brothers after one of its traders amassed huge losses on Nikkei 225 Index futures. However, neither of these failures appear to have had a negative effect on the commercial banking system.

\subsection{The twenty-first-century crisis}

As can be clearly seen from Fig. 1 and Table 2, the collapse of the banking system in 2007-8 is of a totally different order of magnitude than all previous crises. In terms of negative returns, this 
crisis is unparalleled, with returns of -26.87 per cent and -76.50 per cent in 2007 and 2008 respectively. In total, six of the nine big British banks were insolvent, with over half of the domestic banking system in terms of total assets requiring a bailout. The scale of the 2007-8 instability is apparent in Table 2, with the stock of the worst performing bank in either year falling by more than 90 per cent, far beyond any fall in any other year over the 181-year sample period. Indeed, the fall in bank stock prices was only arrested by the extraordinary support measures taken by the Bank of England and UK Treasury. Consequently, we can truly say of the $2007-8$ crisis that 'this time is different'!

\subsection{Summary}

Several of the banking crises identified by Reinhart and Rogoff (2009) do not manifest themselves in our data. This arises because of the definition used by Reinhart and Rogoff (2009), which means that the failure of one financial institution constitutes a crisis. Quite clearly, the idiosyncratic failures of the City of Glasgow Bank in 1878, Barings in 1890, Johnson Matthey Bankers in 1984, BCCI in 1991, and Barings in 1995 were not viewed as banking crises by contemporaries and therefore do no manifest themselves in our data. This demonstrates the limitations of the qualitative definition of banking crises used in many studies of banking crises.

\section{Leading Indicators of Banking Instability}

In this section, we examine macroeconomic variables to see if they prove to be leading predictors of UK banking instability over the long run. Panel A of Table 3 presents changes in these variables in the years before, during and after the twelve UK banking crises which have been documented by Reinhart and Rogoff (2009). Five things are worthy of note. First, there are on average large positive real equity returns two years before crises followed by large negative returns the year of banking crises. Second, real interest rates and inflation are higher than their 
historical averages in the two years before these crises, as is real GDP growth, which shows an acceleration of economic activity in the year before crises. Third, broad money supply growth is also consistently higher than the sample average in the years leading up to banking crises. Fourth, changes in wheat prices, a proxy for commodities, are on average negative two years before a banking crisis; however, price growth outstrips its historical average by many times in the year before and the year of these crises. Fifth, bank lending and house price growth show large above average increases in the years leading up to banking crises, which would support the view that significant credit growth and house price growth fuelled by easy credit may trigger financial instability. Panel B of Table 3 presents figures for the most significant individual periods of banking instability in our sample, namely those events in which 10 per cent or more of all banks lost more than 20 per cent of their market value. Several of the trends visible in Panel A are again evident in individual nineteenth and twentieth century crises, highlighting similarities in the origin and evolution of banking instability. However, there are also interesting differences in variable changes around the crises in Panel B. Specifically, in the years before the 1878 crisis, which had its origins in an idiosyncratic bank collapse, real interest rates are high and lending growth, inflation and real equity returns are relatively low. It is also interesting to note that, on average, GDP growth is positive in the years following crises documented by Reinhart and Rogoff (2009) (Panel A). However, for the four most severe crises (see Panel B), GDP growth is negative in the year following the crisis.

\section{< TABLE 3 HERE >}

While Table 3 highlights these relationships during specific periods of banking crises, we now turn to examine if there is a statistically significant relationship between these variables and banking instability over the long run using our full sample. Specifically, multiple dimension VAR models and Granger causality tests are used in order to determine if there is any statistically 
significant relationship between various macroeconomic variables and the level of British banking instability.

Prior to the analysis of the linkages between macroeconomic variables and financial instability, the specification of the functional form of the system, such as lag order was determined. Various lag order selection criteria tests, including the Akaike, Schwarz, and Hannan-Quinn information criterion, indicate the optimum lag length to be two. In addition, Dickey-Fuller tests were used to test for stationarity. All variables, with the exception of exchange rates, were stationary; the exchange rate variable was therefore transformed to ensure stationarity. Due to the presence of heteroskedasticity and autocorrelation in some variables, the model is run using heteroskedasticity- and autocorrelation-consistent standard errors.

Tests are carried out for three main periods. First, tests are run for 1860-2010, the period for which we have bank lending and risk premium data. Second, the full dataset of bank share prices from $1835-2010$ is tested. ${ }^{8}$ Third, tests are also run on the period for which we have UK house-price data i.e., 1901-2010. The absolute value of average bank returns, a non-parametric measure of volatility, is used as the baseline measure of banking instability. These tests are rerun using drawdown of bank returns, measured by the change in an index of bank returns from its previous historical peak, nominal bank returns, and volatility of bank returns, measured by the non-overlapping annual standard deviation of average monthly returns.

The results of Granger causality tests for our baseline model are shown in Panel A of Table 4. For this section, we only report Granger causality results following the VAR which depict the relationship between all variable lags and our variable of interest, banking instability, for our three time periods (the full matrices of Granger causality results following all VAR models are reported in the Appendix Tables). These tests examine the null hypothesis that the lags of all the variables included in each model (Columns 3-14) do not Granger cause changes in

\footnotetext{
${ }^{8}$ The years $1830-34$ are dropped due to volatility caused by too few observations.
} 
the variable in Column 2. From the first row of Panel A Table 4, we can reject the null hypothesis for several indicators. It appears that indicators which consistently Granger cause changes in UK banking stability from 1860-2010 are; real equity return growth, bank lending growth, money supply growth, real rates of interest, inflation, and net public debt growth. Lags of lending, interest rates, and inflation are significant at the one per cent level and equity returns, money supply, and public debt are significant at the five per cent level.

\section{$<$ TABLE 4 HERE $>$}

Row 2 of Panel A Table 4 shows the results for the full sample period (1835-2010). These results confirm that real equity returns, money supply, real rates of interest, and inflation are significant predictors of changes in UK banking stability over the long-run. Lags of interest rates and inflation are again significant at the one per cent level.

The above results are consistent with our predictions and with findings from most indicator models of financial crisis in the extant literature. Exchange rates do not appear to explain changes in banking stability during this period in any test, supporting the findings of Eichengreen and Arteta (2000). Our findings also suggest that commodity prices (proxied by wheat prices) and output also do not significantly explain changes in banking stability.

The final row of Panel A Table 4 presents the results for the period 1901-2010. Granger causality tests are largely consistent with the results from the previous two periods. Real interest rates and inflation again prove to be indicators of changes in banking instability. There is also further evidence that changes in bank lending growth, real equity returns, money supply growth and net public debt growth are significant predictors of instability. It appears that house price growth is not a significant predictor of banking instability during this sample period. While house price bubbles have been associated with banking instability in the recent past, this may not have always been the case. Notably, there have been several periods of strong house price growth during the sample period, which were not associated with banking instability. 
Several of these results are robust across alternative measures of banking instability. Panel B of Table 4 includes results of Granger causality tests when the above specifications are rerun, replacing absolute bank returns with drawdown, nominal bank returns and standard deviation of bank returns as the measure of instability. Using drawdown of bank returns as a measure of instability, results suggests that real equity returns, lending growth, inflation and real rates of interest are significant indicators of changes in banking instability over the long-run, which is consistent with the results above.

Using nominal bank returns and standard deviation of bank returns as measures of instability also show that lags of real interest rates, inflation, and bank lending growth Granger cause changes in bank instability. However, real equity returns is not a significant predictor of banking instability at the 10 per cent level. Interestingly, for the standard deviation of bank returns, the addition of house prices indicates that they have explanatory power for changes in bank share price volatility at the 10 per cent level.

The correlation matrix between VAR variable residuals, which captures contemporaneous relationships between variables, is presented in Table 5. Notably, there is a positive correlation between our banking instability variable and the risk premium, real equity market returns, lending growth and inflation, all of which are statistically significant. There is also a negative correlation with the real interest rate, significant at the five per cent level, which could be attributed to increased bank earnings over the short run, following interest rate rises.

\section{<TABLE 5 HERE >}

Fig. 4 displays the impulse responses of banking instability to a one standard error shock to each indicator variable, with 90 per cent confidence intervals. These functions give a clearer picture of the direction of the relationship between variables. From Fig. 4, we see that instability rises in response to a positive shock to money supply and inflation, with the peak response occurring after one to two years. A shock to bank lending growth is also associated with 
increased instability. However, instability decreases one year after a positive shock to real equity returns and a positive shock to real interest rates only slightly increases instability after one year. In order to determine how much the ordering of our variables in the VAR matters, Fig. 5 uses the reverse of the ordering used in Fig. 4. The results in Fig. 5 are largely similar to those in Fig. 4, with the main difference being the response of banking instability to a shock to real interest rates and inflation, with the effect of inflation being decreased and the effect of real interest rates becoming more pronounced. In this analysis, inflation is allowed to affect interest rates contemporaneously, where the reverse was true in Fig. 4. A positive shock to the real interest rate variable increases banking instability sharply in the first year in this ordering, while a positive shock to inflation results in a small increase in instability, which disappears after two years.

\section{$<$ FIGS. 4 \& 5 HERE $>$}

The question arises to how the regulatory environment and the safety net affect bank behaviour in a particular macroeconomic environment. For example, low interest rates and high equity returns may not stimulate a credit expansion if it is constrained by regulation. On the other hand, the presence of a safety net may incentivise banks to expand credit and increase the risk of their portfolio. Interestingly, in the case of the UK, there were substantial restraints on credit from World War II until the early 1970s (Turner, 2014, pp.181-6). This corresponds to a very stable period in British banking. Correspondingly, the credit growth prior to 2008, occurred in a very lax regulatory environment with a substantial safety net. The institutional setting will therefore also be an important determinant of how banks behave and whether credit grows. However, over the long-run, the key results in this section suggest that credit growth, equity returns, inflation and real rates of interest are important leading indicators of banking instability.

\section{Banking Instability and Credit}


In this section, we evaluate whether banking instability in the UK is associated with an increase in the credit-risk premium. The average yield spread of UK corporate bonds over long-dated government bonds is used as a measure of the credit risk premium and a proxy for the cost of credit intermediation (Fig. 6).

<FIG. 6 HERE >

As not all crises documented by Reinhart and Rogoff (2009) appear to be associated with significant instability in the banking sector, we begin by analysing changes in the corporate bond risk premium in two specific subsamples of banking instability: (1) all periods highlighted as banking crises in Reinhart and Rogoff (2009) and (2) four individual periods of the most severe instability, which are defined as events in which 10 per cent or more of all banks lost greater than 20 per cent of their market value.

Panel A of Table 6 reports average values of bank returns and our risk premium variables in the two years before and after all UK banking crisis documented by Reinhart and Rogoff (2009) for the period 1830-2010. We can see that on average, bank returns fall sharply in the year of these episodes, falling 9.24 per cent. Furthermore, there is a significant increase in the corporate bond risk premium during these episodes, suggesting a strong relationship between banking instability and higher credit costs for companies. The yield differential increases significantly, with an average increase of over 40 per cent from year $t_{-1}$ to $t_{0}$. When we limit the sample to just the higher risk firms, which are more likely to be small, the increase in the cost of credit is much greater in absolute terms. The risk premium of the lower risk firms increases to a much smaller degree, on average, during banking difficulties. From Panel A, it is also apparent that for the two years following the episode, yield spreads remain persistently higher, on average, for the high-risk firms than in the years immediately before the crisis.

$<$ TABLE 6 HERE> 
This evidence may corroborate the view that it is the smallest borrowers that are disproportionally hit by severe instability (Bernanke 1983, pp. 264-265; Calomiris and Mason, 2003; Frederiksen 1931, p.131). While these risk premium changes undoubtedly reflect normal changes in default risk across the business cycle, the relationship between large increases in this risk premium during significant banking difficulties is clear.

Panel B of Table 6 analyses the four most severe periods of instability in our sample individually in order to ascertain whether these events evolve similarly, or if there is variation in how the cost of credit reacts. Panel B shows that across all periods, the corporate bond risk premium increases for the higher risk sample; however the increases are much more severe during the most recent crises. The risk premium for lower risk firms increases to a much lesser extent during these events. Interestingly, during the 1974 banking instability, while we see large increases in the risk premium of our higher risk firms, the premium of the lower risk sample decreases significantly, indicating a 'flight to quality'. This is then reversed, to a degree, as the premium for higher risk firms falls in the years following 1974.

If we look specifically at changes in the yield differential around the recent 2007-8 banking crisis, we can see that this is by far the most severe episode of banking instability in our sample. First, the decline in bank returns is the largest of any sub-sample. From 2006 to 2008, the average corporate bond risk premium in our sample increased from 0.77 per cent to 2.76 per cent. This represents an increase of 258 per cent in the risk premium firms had to pay to raise money on the bond market in the UK. This is by far the largest annual increase throughout the entire sample period. The British government and the Bank of England claimed to have opened channels of credit to individuals and small businesses affected by this banking crisis. Panel B indicates that these policies may have been successful in that the average cost of credit to all businesses had returned to a more normal level by 2009 . 
The results in Table 6 support the view that significant banking instability is accompanied by large increases in the cost of credit to businesses, and it is the riskiest/smallest firms which suffer the most and/or longest. In the remainder of this section, we examine if there is a statistically significant link between overall banking instability and the corporate bond risk premium. In order to do this, we present further results from the earlier VAR models and Granger causality tests, now focusing on how lags of all variables in the system affect the risk premium variable, with additional results focusing on our subsamples of low-risk firms and highrisk firms (Table 7).

The null hypothesis for these tests is that the lags of variables in Columns 3-12 of Table 7 have no significant effect on the variable in the 'Dependent Variable' column. From Row 1 of Panel A, we see that there is strong evidence that instability in the banking sector Granger causes changes in the corporate bond risk premium at around the one to two per cent significance level (Column 3). This result adds weight to the belief that banking instability is associated with a breakdown in the ability of markets to channel funds from lenders to borrowers. Banking instability is also a predictor of changes in the risk premium at the one per cent significance level for both risk premium sub-groups.

\section{<TABLE 7 HERE >}

It is interesting to note that lags of the returns on the equity market have significant predictive power for the credit-risk premium at the one per cent level for low-risk firms (Row 3, Panel A). This would suggest that the general condition of corporations in the market plays a significant role in explaining the cost of credit premium that these firms face over the long run, as one would expect. However, this effect is not present for the most risky subset of firms (Row 2, Panel A), which may suggest that changes in the risk premium of this subset are actually less related to the past condition of corporations. Similar results are evident in Panel B which presents results using alternative measures of instability. This, again, may support the belief that it is the 
smallest borrowers that are disproportionally affected by banking instability, with projects which in normal times would be funded, frozen from credit markets due to banking difficulties (Bernanke 1983, pp. 264-5).

While banking instability itself is consistently a significant predictor of changes in GDP (Appendix Table 2), we do not find evidence of significance at the 10 per cent level that changes in lags of the risk premium Granger cause direct changes in real GDP growth over the full sample. This may be because such a link is only significant during periods of extreme instability and large increases in the risk premium. An alternative explanation may be that changes in the risk premium affects GDP through a transmission mechanism via changes in the equity market, as there is a significant relationship running from risk premium to equity returns and equity returns to GDP in this model (Appendix Table 2). It also appears that any direct effect decreases further as we move to the more risky subset of firms, suggesting an importance of large (less risky firms) for economic growth.

There is also evidence in Appendix Table 2 that banking instability Granger causes changes in the money supply in the UK over the long run. In addition, lags of money supply have consistent predictive power for output changes, as would be suggested by the monetary transmission mechanism. This finding offers some support to the Friedman and Schwartz (1963) view that banking difficulties may exacerbate the economic condition of a country through the monetary channel.

\section{Conclusions}

This paper uses 181 years of bank share prices to develop a new measure of British banking instability over the long run. We find that the British banking system has faced several episodes of instability throughout this period. However, our evidence suggests that banking instability in the UK has grown more severe in the final quarter of the twentieth century, culminating in by far 
the largest banking crisis in our sample in 2007-8. The ultimate roots of the 2007-8 banking difficulties, as with previous periods of banking instability, are likely to be found in regulatory failures and in the political economy of banking (Rajan, 2010; Calomiris and Haber, 2014; Turner, 2014). While macroeconomic conditions may not have been the main or ultimate cause, they may have played a role in triggering or exacerbating banking difficulties.

In order to investigate potential macroeconomic causes of banking instability, we use a series of vector autoregressions and our unique dataset to establish which variables consistently act as significant indicators of instability over the long run. We find that interest rates, inflation, bank lending growth, and equity prices routinely act as indicators of changes to overall banking instability in the UK over the last two centuries. This suggests that stability of these factors should be an important policy goal. Finally, in terms of consequences of banking instability, we find long-run evidence that banking instability consistently acts as a significant predictor of changes in the credit-risk premium that all businesses face, particularly small firms. This implies that the policy response during crises should be designed with this in mind. More fundamentally, however, given these costs of banking instability to small firms and the economy at large, an appropriate regulatory structure needs to be devised which lessens the probability of future crises occurring. 


\section{References}

Acheson G.G., Turner, J.D., 2008. The Death Blow to Unlimited Liability in Victorian Britain: the City of Glasgow Failure. Explorations in Economic History 45, 235-53.

Alchian, A.A., Kessel, R.A., 1962. Effects of Inflation. Journal of Political Economy 70, 521-37.

Allen, F., Gale, D., 2000. Bubbles and Crises. Oxford Review of Economic Policy 15, 9-18.

Altman, E., Gande, A., Saunders, A., 2010. Informational Efficiency of Loans versus Bonds: Evidence from Secondary Market Prices. Journal of Money, Credit and Banking 42, 755-767.

Baker, M., Collins, M., 1999. Financial Crises and Structural Change in English Commercial Bank Assets, 1860-1913. Explorations in Economic History 36, 428-44.

Banking Almanac and Yearbook (1845-1930).

Bank for International Settlements, BIS Annual Report, 1983-1988.

Bank for International Settlements. 2011. BIS Quarterly Review: International Banking and Financial Market Developments. Basel: BIS.

Bank of England Interactive Database 2011.

Barclays Equity Gilt Study 2011.

Belfast Newsletter, 1830-68.

Bergman, M.U., Hansen, J., 2002. Financial Instability and Monetary Policy: The Swedish Evidence. Sveriges Riksbank Working Paper Series, 137.

Bernanke, B., 1983. Nonmonetary Effects of the Financial Crisis in the Propagation of the Great Depression. American Economic Review 73, 257-76.

Bernanke, B., Gertler, M., 1989. Agency Costs, Net Worth, and Business Fluctuations. American Economic Review 79, 14-31.

Bernanke, B., Gertler, M., 1990. Financial Fragility and Economic Performance. Quarterly Journal of Economics 105, 87-114.

Bernanke, B., Gertler, M., 1995. Inside the Black Box: The Credit Channel of Monetary Policy Transmission. NBER Working Papers, 5146.

Bloomberg L.P., 2003-2010.

Bordo, M.D., Haubrich, J.G., 2010. Credit Crises, Money and Contractions: An Historical View. Journal of Monetary Economics 57, Issue 1, 1-18. 
Bordo, M.D., Dueker, M.J., Wheelock, D.C., 2003. Aggregate Price Shocks and Financial Stability: The United Kingdom 1796-1999. Explorations in Economic History 40, $143-$ 69.

Bordo, M., Eichengreen, B., Klingebiel, D., Martinez Peria, S.M., 2001. Is the Crisis Problem Growing More Severe? Economic Policy 24, 51-82.

Borensztein, E., Lee, J-W., 2000. Financial Crisis and Credit Crunch in Korea-Evidence from Firm-Level Data. IMF Working Papers, 00/25.

Borio, C., Lowe, P., 2002. Asset Prices, Financial and Monetary Stability: Exploring the Nexus, Bank for International Settlements Working Paper 114.

Burdetts Official Intelligence, 1882-98.

Butt, N., Pugh, A., 2014. Credit spreads: Capturing Credit Conditions Facing Households and Firms. Bank of England Quarterly Bulletin 54, 137-47.

Calomiris, C.W., Mason, J.R., 2003. Consequences of Bank Distress during the Great Depression. American Economic Review 93, 937-47.

Calomiris, C.W., Haber, S.H., 2014. Fragile by Design: The Political Origins of Banking Crises and Scarce Credit. Princeton: Princeton University Press.

Capie, F., 2010. The Bank of England, 1950s to 1979. Cambridge: Cambridge University Press.

Capie F., Webber, A., 2010. A Monetary History of the United Kingdom: 1870-1982. London: Routledge.

Capie, F., Wood, G., 2012. Money Over Two Centuries: Selected Topics in British Monetary History, Oxford: Oxford University Press.

Caprio, G., Klingebiel, D., 1996. Bank Insolvency: Bad Luck, Bad Policy, or Bad Banking? in Annual World Bank Conference on Development Economics, Washington, D.C.: World Bank.

Christiano, L.J., Motto, R., Rostagno, M., 2010. Financial Factors in Economic Fluctuations. European Central Bank Working Paper Series 1192.

Churm, R., Webber, L., 2007. Decomposing Corporate Bond Spreads. Bank of England Quarterly Bulletin 47, 533-541.

Clapham, J.H., 1944. The Bank of England: A History, 2 volumes, Cambridge: Cambridge University Press.

Collins, M., 1990. Money and Banking in the UK: a History. London: Routledge.

Collins, M., Baker, M., 2003. Commercial Banks and Industrial Finance in England and Wales, 1860-1913. Oxford: Oxford University Press. 
Cotter, J., 2004. Absolute Return Volatility. Geary WP2004/15.

Course of the Exchange, 1840-71.

Coyle, C., Turner, J.D., 2013. Law, Politics and Financial Development: The Great Reversal of the U.K. Corporate Debt Market. Journal of Economic History 73, 810-846.

Datastream, 1965-2010.

Davidian, M., Carroll, R.J., 1987. Variance Function Estimation. Journal of the American Statistical Association 82, 1079-1091.

Davis, E.P., Karim, D., 2008. Comparing Early Warning Systems for Banking Crises. Journal of Financial Stability 4, 89-120.

Deaton, A., 2012. The Financial Crisis and the Well-being of Americans. Oxford Economic Papers 64, 1-26.

Demirgüç-Kunt, A., Detragiache, E., 1998a. Financial Liberalization and Financial Fragility. International Monetary Fund Working Paper, WP/98/83.

Demirgüç-Kunt, A., Detragiache, E., 1998b. The Determinants of Banking Crises in Developing and Developed Countries. IMF Staff Papers 45, No.1.

Demirgüç-Kunt, A., Detragiache, E., 1999. Monitoring Banking Sector Fragility: A Multivariate Logit Approach with an Application to the 1996/97 Banking Crises. IMF Mimeo.

Demirgüç-Kunt, A., Detragiache, E., Gupta, P., 2006. Inside the Crises: An Empirical Analysis of Banking Systems in Distress. Journal of International Money and Finance 25, 702-18.

Department for Communities and Local Government. 2011. Housing Market: House Prices from 1930, Annual House Price Inflation, United Kingdom, from 1970. London: DCLG.

Dimson, E., Marsh, P., Staunton, M., 2011. Credit Suisse Global Investment Sourcebook 2010, Zurich: Credit Suisse.

Ding, W. Domac, I., Ferri, G., 1998. Is There a Credit Crunch in East Asia? Policy Research Working Paper Series, World Bank.

Ding, Z., Granger, C., Engle, R., 1993. A Long Memory Property of Stock Market Returns and a New Model. Empirical Finance 1, 83-106.

Eichengreen, B., Arteta, C., 2000. Banking Crises in Emerging Markets: Presumptions and Evidence, Centre for International Development Economics Research Working paper, Haas School of Business, 115.

Flamini, A., Milas, C., 2015. Distribution Forecast Targeting in an Open-Economy, Macroeconomic Volatility and Financial Implications. Journal of Financial Stability 16, 89-105. 
Forsberg, L., Ghysels, E., 2007. Why Do Absolute Returns Predict Volatility So Well? Journal of Financial Econometrics 5, 31-67.

Frederiksen, D.M., 1931. Two Financial Roads Leading Out of Depression. Harvard Business Review 10, 131-48.

Friedman, M., Schwartz, A.J., 1963. A Monetary History of the United States, 18671960. Princeton, N.J.: Princeton University Press for NBER.

Gavin, M., Hausmann, R., 1996. The Roots of Banking Crises: the Macroeconomic Context. Inter-American Bank Working Paper 318, 1-20.

Global Financial Data, 1930-1964.

González-Hermosillo, B., 1999. Determinants of Ex-ante Banking System Distress: A MacroMicro Empirical Exploration of Some Recent Episodes. IMF Working paper, 99/33.

Goodhart, C., Delargy, P.J.R., 1998. Financial Crises: Plus Ca Change, Plus Cest La Meme Chose. International Finance 1. 261-88.

Gourinchas, P-O., Valdes, R., Landerretche, O., 2001. Lending Booms: Latin America and the World. Economia: Journal of the Latin American and Caribbean Economic Association $1,47-89$.

Granger, C., Sin, C., 2000. Modelling the Absolute Returns of Different Stock Market Indices: Exploring the Forecastability of an Alternative Measure of Risk. Journal of Forecasting 19, 277-298.

Gregory, T.E., 1936. The Westminster Bank through a Century, Oxford University Press, 2.

Grossman, R.S., 1994. The Shoe That Didn't Drop: Explaining Banking Stability During the Great Depression. Journal of Economic History 53, 654-82.

Grossman, R.S., 2010. Unsettled Account: The Evolution of Banking in the Industrialised World Since 1800. Princeton: Princeton University Press.

Hall, R.E., 2010. Why Does the Economy Fall to Pieces after a Financial Crisis? Journal of Economic Perspectives 24, 3-20.

Hardy, D., Pazarbasioglu, C., 1998. Leading Indicators of Banking Crises: Was Asia Different? IMF Working Paper no. WP/98/91 (June).

Hoggarth, G., Reis, R., Saporta, V., 2002. Costs of Banking System Instability: Some Empirical Evidence. Journal of Banking and Finance 26, 825-55.

Holmes, A.R., Greene, E., 1986. Midland: 150 Years of Banking Business, London.

Holmstrom, B., Tirole, J., 1997. Financial Intermediation, Loanable Funds, and the Real Sector. Quarterly Journal of Economics 112, 663-91. 
International Monetary Fund. 1998. World Economic Outlook, Washington, D.C.: IMF (May). Investors Monthly Manual, 1864-1929.

Jefferys, J.B., 1977. Business Organisation in Great Britain 1856-1914, New York: Arno Press.

Jordà, Ò., Schularick, M., Taylor, A.M., 2011. Financial Crises, Credit Booms, and External Imbalances: 140 Years of Lessons. IMF Economic Review 59, 340-378.

Jordà, Ò., Schularick, M., Taylor, A.M., 2014. Betting the House. Journal of International Economics 96. 2-18.

Kaminsky, G.L., Reinhart, C.M., 1999. The Twin Crises: The Causes of Banking and Balanceof-Payments Problems. American Economic Review 89, 473-500.

Kaufman, G., 1999. Banking and Currency Crises and Systemic Risk: A Taxonomy and Review. Loyola University Chicago and Federal Reserve Bank of Chicago mimeo.

Kiyotaki, N., Moore, J., 1997. Credit Cycles. Journal of Political Economy 105, 211-48.

Krishnamurthy, A., 2010. How Debt Markets Have Malfunctioned in the Crisis. Journal of Economic Perspectives 24, 3-28.

Laeven, L., 2011. Banking Crises: A Review. Annual Review of Financial Economics 3, 17-40.

Laeven, L., Valencia, F., 2010. Resolution of Banking Crises: The Good, the Bad, and the Ugly. IMF Working Paper WP/10/146.

Liesner, T., 1989. One Hundred Years of Economic Statistics: United Kingdom, United States of America, Australia, Canada, France, Germany, Italy, Japan, Sweden. London: Economist Publications.

Logan, A., 2001. The UK Small Banks Crisis of the Early 1990s: What Were the Leading Indicators of Failure? Bank of England Working Paper.

London Gazette, 1980-2010.

McKinnon, R.I., Pill, H., 1997. Credible Economic Liberalizations and Over borrowing. American Economic Review 87, 189-93.

Minsky, H.P., 1977. The Financial Instability Hypothesis: An Interpretation of Keynes and an Alternative to Standard Theory. Nebraska Journal of Economics and Business 16, 5-16.

Mishkin, F.S., 2009. Is Monetary Policy Effective During Financial Crises. American Economic Review 99, 573-577.

Mishkin, F.S., 1991. Asymmetric Information and Financial Crises: a Historical Perspective, in G.R. Hubbard (eds.), Financial Markets and Financial Crises, University of Chicago Press, Chicago, 69-108. 
Mitchell, B.R., 1988. British Historical Statistics. Cambridge: Cambridge University Press.

O’Donoghue, J., Goulding, L., Allen, G., 2004. Composite Price Index, 1750-2003. Economic Trends 604, 38-46.

Officer, L.H., 2011. Dollar-Pound Exchange Rate from 1791, MeasuringWorth.

Officer, L.H., 2011. What Was the Interest Rate Then? MeasuringWorth.

Officer, L.H., 2011. What Was the U.K. GDP Then? Measuring Worth.

Rait, R.S., 1930. The History of the Union Bank of Scotland. Glasgow: John Smith and Son.

Rajan, R.G., 2010. Fault Lines: How Hidden Fractured Still Threaten the World Economy. Princeton: Princeton University Press.

Register of Defunct Companies, 1979-2002.

Reid, M., 1982. The Secondary Banking Crisis 1973-75: its Causes and Course. London: Macmillan.

Reinhart, C., Rogoff, K., 2009. This Time is Different. Eight centuries of Financial Folly. Princeton University Press, Princeton, NJ, US.

Reinhart, C.M., Rogoff, K.S., 2008. Banking Crises: An Equal Opportunity Menace. NBER Working Paper, 14587.

Sayers, R.S., 1976. The Bank of England: 1891-1944, 2 vols., Cambridge: Cambridge University Press.

Schularick, M., Taylor, A.M., 2012. Credit Booms Gone Bust: Monetary Policy, Leverage Cycles, and Financial Crises, 1870-2008. American Economic Review 102, 1029-61.

Sheppard, D.K., 1971. The Growth and Role of UK Financial Institutions 1880-1962. London: Methue.

Statistical Abstract for the United Kingdom, 1871-1913.

Stock Exchange Daily Official List, 1930-2002.

Stock Exchange Official Intelligence, 1899-1933.

Stock Exchange Official Yearbook, 1876-2002.

Stock Exchange, 1979. Register of Defunct and Other Companies Removed from the Stock Exchange Official Year-book. East Grinstead: Thomas Skinner and Co.

Taylor, A., 2012. The Great Leveraging. NBER Working Paper 18290.

The Annual Statistical Abstract for the United Kingdom, 1871-1913. 
The Bankers Magazine, 1859-1881.

The Scotsman, 1834-1867, 1930-38.

The Times, 1930-1964.

Turner, J., 2014. Banking in Crisis: The Rise and Fall of British Banking Stability, 1800 to the Present. Cambridge: Cambridge University Press.

Valencia, F., Laeven, L., 2012. Systemic Banking Crises Database: An Update. IMF Working Papers 12/163, International Monetary Fund.

Van den End, J.W., 2006. Indicator and Boundaries of Financial Stability. DNB Working Paper, no. 97.

Wong, J., Wong, T.-C., Leung, P., 2010. Predicting Banking Distress in the EMEAP Economies. Journal of Financial Stability 6, 169-179 
Table 1.

Summary Statistics.

\begin{tabular}{|c|c|c|c|c|c|c|c|}
\hline & Mean & Median & $\begin{array}{l}\text { Standard } \\
\text { Deviation }\end{array}$ & Minimum & Maximum & $\begin{array}{c}\% \text { of } \\
\text { Years }<0\end{array}$ & $\begin{array}{l}\text { No. of } \\
\text { Obs. }\end{array}$ \\
\hline $\begin{array}{c}\text { Average Bank } \\
\text { Returns }(\%)\end{array}$ & 5.32 & 2.60 & 20.32 & -76.50 & 154.64 & 34.81 & 181 \\
\hline $\begin{array}{l}\text { Absolute Bank } \\
\text { Returns (\%) }\end{array}$ & 11.92 & 6.24 & 17.26 & 0.01 & 154.64 & $\mathrm{n} / \mathrm{a}$ & 181 \\
\hline $\begin{array}{c}\text { Annual SD of } \\
\text { Bank Returns (\%) }\end{array}$ & 2.99 & 1.70 & 3.09 & 0.30 & 18.86 & $\mathrm{n} / \mathrm{a}$ & 181 \\
\hline $\begin{array}{c}\text { Corporate Bond } \\
\text { Risk Premium (\%) }\end{array}$ & 0.94 & 1.07 & 0.96 & -2.28 & 2.86 & 12.58 & 151 \\
\hline Drawdown $(\%)$ & -3.82 & -2.19 & 19.78 & -82.81 & 51.76 & 58.56 & 181 \\
\hline $\begin{array}{c}\text { High Risk } \\
\text { Premium 1/2 (\%) }\end{array}$ & 1.81 & 1.60 & 0.82 & 0.19 & 4.29 & 0.00 & 151 \\
\hline $\begin{array}{c}\text { Low Risk } \\
\text { Premium 1/2 (\%) }\end{array}$ & 0.08 & 0.60 & 1.34 & -5.14 & 1.49 & 23.18 & 151 \\
\hline Real Interest (\%) & 1.70 & 2.28 & 5.31 & -20.83 & 18.43 & 24.86 & 181 \\
\hline $\begin{array}{l}\text { GDP Growth } \\
\text { (Nominal, \%) }\end{array}$ & 4.73 & 5.02 & 6.10 & -17.87 & 26.27 & 18.33 & 180 \\
\hline $\begin{array}{l}\text { GDP Growth } \\
\text { (Real, \%) }\end{array}$ & 2.00 & 2.34 & 2.93 & -9.80 & 9.92 & 18.89 & 180 \\
\hline $\begin{array}{l}\text { M3 Money Supply } \\
\text { Growth (\%) }\end{array}$ & 8.89 & 4.90 & 14.94 & -7.54 & 140.82 & 13.07 & 176 \\
\hline Inflation (\%) & 2.76 & 1.80 & 6.05 & -14.00 & 25.20 & 27.62 & 181 \\
\hline $\begin{array}{l}\text { Equity Returns } \\
\text { (Nominal, \%) }\end{array}$ & 10.86 & 10.16 & 17.73 & -48.80 & 145.60 & 20.44 & 181 \\
\hline $\begin{array}{l}\text { Equity Returns } \\
\quad(\text { Real, \%) }\end{array}$ & 8.10 & 7.60 & 18.04 & -64.80 & 121.40 & 26.52 & 181 \\
\hline $\begin{array}{l}\text { Wheat Price Growth } \\
(\%)\end{array}$ & 2.90 & 1.52 & 19.22 & -34.86 & 100.00 & 44.75 & 181 \\
\hline Exchange Rate & 3.98 & 4.79 & 1.50 & 1.30 & 9.97 & $\mathrm{n} / \mathrm{a}$ & 181 \\
\hline $\begin{array}{l}\text { Public Net Debt } \\
\text { Growth (\%) }\end{array}$ & 4.47 & 0.00 & 13.06 & -10.96 & 95.37 & 29.83 & 181 \\
\hline $\begin{array}{l}\text { House Price Growth } \\
(\%)\end{array}$ & 5.65 & 3.45 & 7.63 & -15.79 & 34.83 & 10.00 & 110 \\
\hline $\begin{array}{l}\text { Bank Lending Growth } \\
(\%)\end{array}$ & 7.36 & 5.00 & 10.73 & -14.00 & 65.00 & 19.21 & 151 \\
\hline
\end{tabular}

Notes: The corporate bond risk premium is the excess of current yield on debentures over and above Consols or high-coupon, long-dated government bonds. The corporate bond risk premium over government bonds is further categorised into two subsets: High Risk Premium 1/2 (highest $50 \%$ of yields) and Low Risk Premium 1/2 (lowest 50\% of yields). 
Table 2.

Performance of bank stocks during banking crises documented by Reinhart and Rogoff (2009).

\begin{tabular}{|c|c|c|c|c|c|c|c|c|c|}
\hline \multirow{2}{*}{ Crisis } & \multirow{2}{*}{$\begin{array}{c}\text { Banks - } \\
\text { Market } \\
\text { Return } \\
(\%)\end{array}$} & \multicolumn{5}{|c|}{ Per cent of banks to lose $10-50 \%+$ of value } & \multirow{2}{*}{$\begin{array}{l}\text { Total } \\
\text { banks }\end{array}$} & \multirow{2}{*}{ Worst performing bank } & \multirow{2}{*}{$\begin{array}{l}\text { Return of } \\
\text { worst } \\
\text { performing } \\
\text { bank }(\%)\end{array}$} \\
\hline & & $\begin{array}{l}>10 \% \\
\text { loss }\end{array}$ & $\begin{array}{l}>20 \% \\
\text { loss }\end{array}$ & $\begin{array}{l}>30 \% \\
\text { loss }\end{array}$ & $\begin{array}{l}>40 \% \\
\text { loss }\end{array}$ & $\begin{array}{l}>50 \% \\
\text { loss }\end{array}$ & & & \\
\hline \multicolumn{10}{|l|}{ 1836-39 } \\
\hline 1836 & -3.96 & $0 \%$ & $0 \%$ & $0 \%$ & $0 \%$ & $0 \%$ & 14 & Provincial Bank & -6.67 \\
\hline 1837 & -1.32 & $0 \%$ & $0 \%$ & $0 \%$ & $0 \%$ & $0 \%$ & 16 & Provincial Bank & -4.76 \\
\hline 1838 & 3.96 & $0 \%$ & $0 \%$ & $0 \%$ & $0 \%$ & $0 \%$ & 17 & Royal Bank of Scotland & -0.62 \\
\hline 1839 & -0.16 & $0 \%$ & $0 \%$ & $0 \%$ & $0 \%$ & $0 \%$ & 21 & London Joint Stock Bank & -9.26 \\
\hline 1847 & 3.55 & $50 \%$ & $9 \%$ & $0 \%$ & $0 \%$ & $0 \%$ & 22 & North of Scotland & -22.54 \\
\hline 1857 & -1.90 & $35 \%$ & $4 \%$ & $4 \%$ & $0 \%$ & $0 \%$ & 23 & Glasgow Union / Union Bank & -30.58 \\
\hline 1866 & -4.53 & $27 \%$ & $10 \%$ & $7 \%$ & $0 \%$ & $0 \%$ & 30 & $\begin{array}{l}\text { Alliance of London \& } \\
\text { Liverpool }\end{array}$ & -38.14 \\
\hline 1878 & -6.13 & $39 \%$ & $18 \%$ & $2 \%$ & $1 \%$ & $0 \%$ & 106 & Clydesdale & -41.24 \\
\hline 1890 & 0.88 & $1 \%$ & $0 \%$ & $0 \%$ & $0 \%$ & $0 \%$ & 97 & Yorkshire Banking Company & -38.82 \\
\hline 1914 & 7.28 & $0 \%$ & $0 \%$ & $0 \%$ & $0 \%$ & $0 \%$ & 45 & Union of London \& Smiths & -6.02 \\
\hline 1974 & -8.00 & $100 \%$ & $100 \%$ & $100 \%$ & $100 \%$ & $100 \%$ & 7 & Nat. West. Bank & -69.85 \\
\hline 1984 & 25.70 & $14 \%$ & $0 \%$ & $0 \%$ & $0 \%$ & $0 \%$ & 7 & Midland & -16.78 \\
\hline 1991 & 13.33 & $0 \%$ & $0 \%$ & $0 \%$ & $0 \%$ & $0 \%$ & 7 & Barclays & -3.97 \\
\hline 1995 & 22.83 & $0 \%$ & $0 \%$ & $0 \%$ & $0 \%$ & $0 \%$ & 7 & Nat. West. Bank & 28.79 \\
\hline \multicolumn{10}{|l|}{$2007-8$} \\
\hline 2007 & -39.93 & $88 \%$ & $75 \%$ & $38 \%$ & $38 \%$ & $0 \%$ & 8 & Northern Rock & -92.87 \\
\hline 2008 & -35.83 & $100 \%$ & $100 \%$ & $80 \%$ & $80 \%$ & $80 \%$ & 5 & HBOS & -90.36 \\
\hline
\end{tabular}

Notes: As our focus is the state of the overall banking sector in any given period, and we do not have share price data for several of the banks that failed during our sample period, which is further complicated by unlimited liability and nationalisation, failed/nationalised banks are removed from sample at the point of failure/nationalisation and not included as $100 \%$ loss. However, including $100 \%$ losses for failed/nationalised banks in our sample only makes the decline in 2007-8 more standout due to the points mentioned above and due to the large difference in the number of banks in operation across the sample. Dates included are those highlighted by Reinhart and Rogoff (2009) as years in which banking crises occurred. 
Table 3.

Average variable changes during British banking crises documented by Reinhart and Rogoff (2009).

\begin{tabular}{|c|c|c|c|c|c|c|c|c|c|c|c|}
\hline Year $(\mathrm{t})$ & $\begin{array}{c}\text { Average } \\
\text { Bank } \\
\text { returns } \\
(\%) \\
\end{array}$ & $\begin{array}{l}\text { Public } \\
\text { net debt } \\
\text { growth } \\
(\%)\end{array}$ & $\begin{array}{l}\text { Equity } \\
\text { returns } \\
\text { (real, \%) }\end{array}$ & $\begin{array}{l}\text { Interest } \\
\text { rate } \\
(\text { real, \%) }\end{array}$ & $\begin{array}{c}\text { GDP } \\
\text { growth } \\
\text { (real, \%) }\end{array}$ & $\begin{array}{c}\text { Inflation } \\
(\%)\end{array}$ & $\begin{array}{c}\text { Money } \\
\text { supply } \\
\text { growth } \\
(\%)\end{array}$ & $\begin{array}{l}\text { Wheat } \\
\text { price } \\
\text { growth } \\
(\%)\end{array}$ & $\begin{array}{l}\text { Exchange } \\
\text { rate }\end{array}$ & $\begin{array}{c}\text { Bank } \\
\text { lending } \\
\text { growth } \\
(\%)^{*}\end{array}$ & $\begin{array}{c}\text { House } \\
\text { price } \\
\text { growth } \\
(\%)^{*}\end{array}$ \\
\hline \multicolumn{12}{|c|}{ Panel A: All Documented UK Banking Crises, 1830-2010 } \\
\hline-2 & 16.83 & 2.99 & 14.48 & 1.90 & 2.60 & 3.24 & 15.4 & -1.20 & 4.08 & 14.9 & 7.88 \\
\hline-1 & 1.29 & 3.62 & 1.98 & 1.54 & 3.64 & 3.66 & 19.74 & 12.69 & 3.85 & 9.75 & 11.6 \\
\hline 0 & -8.12 & 3.38 & -3.98 & 1.77 & 0.68 & 3.70 & 9.36 & 10.10 & 3.63 & 8.05 & 5.33 \\
\hline 1 & 17.92 & 11.49 & 22.82 & 2.52 & 1.19 & 2.93 & 13.23 & 2.18 & 3.69 & 3.19 & 3.19 \\
\hline 2 & 10.08 & 14.04 & 11.17 & 1.47 & 2.80 & 3.81 & 9.03 & 2.84 & 3.66 & 5.51 & 7.52 \\
\hline \multicolumn{12}{|c|}{ Panel B: Significant UK Banking Instability: 1866, 1878, 1974, 2007-8 } \\
\hline-2 & 12.39 & -1.25 & 15.29 & 4.08 & 1.68 & -0.90 & 13.86 & -10.20 & 9.97 & 42.17 & \\
\hline-1 & -0.81 & 0.00 & 9.26 & 2.30 & 4.23 & 0.90 & 12.46 & 4.08 & 7.69 & 2.25 & \\
\hline 1866 & -7.96 & -1.27 & -3.52 & -3.24 & 1.15 & 6.50 & 15.45 & 19.33 & 6.88 & 2.27 & \\
\hline 1 & -8.93 & 0.00 & 6.15 & -3.02 & -0.94 & 6.10 & 2.30 & 29.11 & 6.75 & -4.75 & \\
\hline 2 & -0.139 & -3.846 & 21.25 & 4.76 & 3.049 & -1.70 & -0.741 & -1.06 & 6.83 & 4.65 & \\
\hline-2 & 1.25 & 1.39 & 6.06 & 3.32 & 0.72 & -0.30 & 0.48 & 2.21 & 5.42 & 1.05 & \\
\hline-1 & 4.62 & 0.00 & 6.72 & 3.71 & 0.63 & -0.70 & -2.88 & 22.88 & 5.08 & 0.77 & \\
\hline 1878 & -9.67 & 0.00 & -0.79 & 5.21 & 0.33 & -2.20 & -3.45 & -18.19 & 4.89 & -2.16 & \\
\hline 1 & -4.11 & 1.37 & 28.29 & 7.34 & -1.90 & -4.40 & -3.92 & -5.6 & 4.85 & -12.01 & \\
\hline 2 & 3.66 & 0.00 & 8.16 & -0.09 & 7.07 & 3.00 & 0.18 & 1.19 & 4.84 & 0.47 & \\
\hline-2 & 48.98 & 7.18 & 11.50 & 1.00 & 3.66 & 7.10 & 23.93 & 18.88 & 2.50 & 28.56 & 30.93 \\
\hline-1 & -27.79 & 2.90 & -33.50 & 0.54 & 7.20 & 9.20 & 26.88 & 72.97 & 2.45 & 28.32 & 34.83 \\
\hline 1974 & -62.85 & 9.71 & -64.8 & -2.66 & -1.31 & 16.00 & 18.26 & 21.88 & 2.34 & 14.95 & 10.54 \\
\hline 1 & 154.64 & 14.68 & 121.4 & -11.2 & -0.62 & 24.20 & 9.51 & -5.13 & 2.22 & 4.49 & 7.25 \\
\hline 2 & -17.99 & 21.96 & -13.6 & -3.46 & 2.63 & 16.50 & 10.48 & 29.39 & 1.80 & 16.93 & 7.78 \\
\hline-2 & 5.14 & 10.76 & 19.96 & 2.99 & 2.17 & 1.34 & 12.20 & 4.50 & 1.82 & 9.04 & 5.83 \\
\hline-1 & 16.10 & 9.20 & 14.35 & 2.12 & 2.85 & 2.05 & 13.90 & 29.56 & 1.84 & 13.02 & 7.37 \\
\hline 2007 & -26.87 & 7.99 & 2.77 & 2.23 & 2.56 & 2.33 & 13.40 & 76.63 & 2.00 & 12.92 & 9.08 \\
\hline 2008 & -76.5 & 5.00 & -33.42 & 2.34 & 0.55 & 2.32 & 10.10 & -32.73 & 1.85 & 13.10 & 1.95 \\
\hline 1 & 7.83 & 17.50 & 28.19 & 0.84 & -4.92 & 3.61 & 5.40 & -1.12 & 1.57 & 2.81 & -0.75 \\
\hline 2 & 9.94 & 23.12 & 9.00 & 2.300 & 1.91 & 2.17 & -1.40 & 53.53 & 1.55 & -1.17 & 11.31 \\
\hline
\end{tabular}

Full sample average

$\begin{array}{lllllllllll}5.38 & 4.47 & 8.10 & 1.70 & 2.00 & 2.76 & 8.89 & 2.90 & 3.98 & 7.36 & 5.65\end{array}$

Notes: Panel A includes all banking crises discussed in Reinhart and Rogoff (2009). Panel B includes the years 1866, 1878, 1974 and 2007-8; periods in which 10 per cent or more of all banks lost more than 20 per cent of their market value (see Table 2). *Bank lending growth is from 1860 onwards and house price growth is from 1901 onwards. Sources: See Appendix Table 1. 
Table 4.

Granger causality tests of macroeconomic indicators of UK banking instability.

\begin{tabular}{|c|c|c|c|c|c|c|c|c|c|c|c|c|c|}
\hline & $\begin{array}{c}\text { Dependant } \\
\text { Variable }\end{array}$ & $\begin{array}{c}\text { Bank } \\
\text { Instability } \\
\text { (P-Value) }\end{array}$ & $\begin{array}{c}\text { Risk } \\
\text { premium } \\
(P \text {-Value })\end{array}$ & $\begin{array}{c}\text { Equity } \\
\text { returns } \\
\text { (real, \%) }\end{array}$ & $\begin{array}{c}\text { Bank } \\
\text { lending } \\
\text { growth } \\
(\%) \\
(P \text {-Value })\end{array}$ & $\begin{array}{c}\text { GDP } \\
\text { growth } \\
\text { (real, \%) }\end{array}$ & $\begin{array}{c}\text { Money } \\
\text { supply } \\
\text { growth } \\
(\%) \\
(P \text {-Value })\end{array}$ & $\begin{array}{l}\text { Inflation } \\
(\%) \\
(P \text {-Value })\end{array}$ & $\begin{array}{c}\text { Interest } \\
\text { rate } \\
\text { (real, \%) } \\
(P \text {-Value })\end{array}$ & $\begin{array}{l}\text { Exchange } \\
\text { Rate } \\
(P \text {-Value })\end{array}$ & 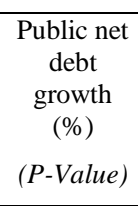 & $\begin{array}{c}\text { Wheat } \\
\text { price } \\
\text { growth } \\
(\%) \\
(P \text {-Value })\end{array}$ & $\begin{array}{c}\text { House } \\
\text { price } \\
\text { growth } \\
(\%) \\
(P \text {-Value })\end{array}$ \\
\hline \multicolumn{14}{|c|}{ Panel A: Absolute returns } \\
\hline $1860-2010$ & Bank Instability & 0.047 & 0.581 & 0.023 & 0.010 & 0.899 & 0.021 & 0.002 & 0.000 & 0.298 & 0.029 & 0.146 & \\
\hline $1835-2010$ & Bank Instability & 0.041 & & 0.013 & & 0.832 & 0.083 & 0.009 & 0.000 & 0.945 & 0.192 & 0.240 & \\
\hline $1901-2010$ & Bank Instability & 0.039 & 0.845 & 0.035 & 0.017 & 0.732 & 0.088 & 0.009 & 0.000 & 0.754 & 0.036 & 0.149 & 0.168 \\
\hline \multicolumn{14}{|c|}{ Panel B: Drawdown } \\
\hline $1860-2010$ & Bank Instability & 0.001 & 0.770 & 0.083 & 0.016 & 0.638 & 0.919 & 0.008 & 0.072 & 0.043 & 0.681 & 0.376 & \\
\hline $1835-2010$ & Bank Instability & 0.000 & & 0.118 & & 0.639 & 0.160 & 0.049 & 0.069 & 0.266 & 0.914 & 0.382 & \\
\hline $1901-2010$ & Bank Instability & 0.006 & 0.651 & 0.066 & 0.241 & 0.241 & 0.729 & 0.000 & 0.015 & 0.197 & 0.621 & 0.360 & 0.623 \\
\hline \multicolumn{14}{|c|}{ Standard deviation of returns } \\
\hline $1860-2010$ & Bank Instability & 0.000 & 0.100 & 0.470 & 0.039 & 0.574 & 0.044 & 0.003 & 0.000 & 0.016 & 0.336 & 0.086 & \\
\hline $1835-2010$ & Bank Instability & 0.000 & & 0.486 & & 0.512 & 0.752 & 0.031 & 0.000 & 0.174 & 0.093 & 0.063 & \\
\hline $1901-2010$ & Bank Instability & 0.000 & 0.335 & 0.475 & 0.152 & 0.451 & 0.002 & 0.005 & 0.001 & 0.695 & 0.222 & 0.098 & 0.094 \\
\hline \multicolumn{14}{|c|}{ Nominal returns } \\
\hline $1860-2010$ & Bank Instability & 0.473 & 0.196 & 0.167 & 0.017 & 0.659 & 0.888 & 0.000 & 0.001 & 0.075 & 0.139 & 0.151 & \\
\hline $1835-2010$ & Bank Instability & 0.591 & & 0.165 & & 0.874 & 0.358 & 0.000 & 0.001 & 0.174 & 0.494 & 0.253 & \\
\hline $1901-2010$ & Bank Instability & 0.567 & 0.043 & 0.146 & 0.049 & 0.416 & 0.997 & 0.000 & 0.000 & 0.645 & 0.124 & 0.086 & 0.556 \\
\hline
\end{tabular}

Notes: Each row represents the p-values from Granger causality tests following a vector autoregression. Only the results relevant to the banking instability variable are presented here. The exchange rate is differenced to ensure stationarity. 
Table 5.

Contemporaneous correlations between variables.

\begin{tabular}{|c|c|c|c|c|c|c|c|c|c|c|c|}
\hline & $\begin{array}{l}\text { Bank } \\
\text { Instability }\end{array}$ & $\begin{array}{l}\text { Risk } \\
\text { Premium } \\
\end{array}$ & $\begin{array}{l}\begin{array}{l}\text { Equity } \\
\text { returns } \\
\text { (real, \%) }\end{array} \\
\end{array}$ & $\begin{array}{l}\text { Bank } \\
\text { lending } \\
\text { growth }(\%) \\
\end{array}$ & $\begin{array}{l}\text { GDP } \\
\text { growth } \\
\text { (real, \%) }\end{array}$ & $\begin{array}{l}\text { Money } \\
\text { supply } \\
\text { growth (\%) }\end{array}$ & $\begin{array}{l}\text { Inflation } \\
(\%)\end{array}$ & $\begin{array}{l}\text { Interest rate } \\
(\text { real, \%) }\end{array}$ & $\begin{array}{l}\text { Exchange } \\
\text { Rate }\end{array}$ & $\begin{array}{l}\text { Public net } \\
\text { debt } \\
\text { growth }(\%)\end{array}$ & $\begin{array}{l}\text { Wheat } \\
\text { price } \\
\text { growth }(\%)\end{array}$ \\
\hline Bank Instability & 1.000 & & & & & & & & & & \\
\hline Risk Premium & $0.142 *$ & 1.000 & & & & & & & & & \\
\hline Equity returns (real, \%) & $0.362 * * *$ & -0.102 & 1.000 & & & & & & & & \\
\hline Bank lending growth (\%) & $0.153 *$ & $-0.173 * *$ & 0.130 & 1.000 & & & & & & & \\
\hline GDP growth (real, \%) & 0.074 & -0.049 & $0.162^{* *}$ & 0.053 & 1.000 & & & & & & \\
\hline Money supply growth (\%) & 0.060 & -0.067 & 0.048 & $0.171 * *$ & $0.350 * * *$ & 1.000 & & & & & \\
\hline Inflation (\%) & $0.153 *$ & -0.015 & $-0.157 *$ & -0.002 & $0.167 * *$ & 0.070 & 1.000 & & & & \\
\hline Interest rate $(\mathrm{real}, \%)$ & $-0.177 * *$ & -0.043 & 0.075 & 0.008 & $-0.192 * *$ & -0.068 & $-0.990 * * *$ & 1.000 & & & \\
\hline Exchange Rate & -0.026 & -0.083 & 0.078 & $0.392 * * *$ & 0.008 & 0.094 & $-0.188 * *$ & $0.191 * *$ & 1.000 & & \\
\hline Public net debt growth (\%) & -0.068 & -0.108 & -0.080 & -0.080 & 0.056 & $0.177 * *$ & $0.345 * * *$ & $-0.327 * * *$ & -0.007 & 1.000 & \\
\hline Wheat price growth $(\%)$ & -0.107 & $-0.181 * *$ & $-0.159 *$ & 0.028 & $0.302 * * *$ & $0.259 * * *$ & $0.339 * * *$ & $-0.318 * * *$ & -0.0990 & $0.201 * *$ & 1.000 \\
\hline
\end{tabular}


Table 6.

Average variable changes during periods of banking instability.

\begin{tabular}{|c|c|c|c|c|}
\hline Year $(\mathrm{t})$ & $\begin{array}{l}\text { Average bank } \\
\text { returns }(\%)\end{array}$ & $\begin{array}{l}\text { Corporate bond } \\
\text { risk premium }(\%)\end{array}$ & $\begin{array}{c}\text { High risk } \\
\text { premium } 1 / 2(\%)\end{array}$ & $\begin{array}{c}\text { Low risk } \\
\text { premium } 1 / 2(\%)\end{array}$ \\
\hline \multicolumn{5}{|c|}{ Panel A: All Documented UK Banking Crises, 1860-2010 } \\
\hline-2 & 16.01 & 0.74 & 1.67 & -0.19 \\
\hline-1 & 0.86 & 0.57 & 1.57 & -0.44 \\
\hline 0 & -9.24 & 0.80 & 1.96 & -0.34 \\
\hline 1 & 22.08 & 0.65 & 1.76 & -0.45 \\
\hline 2 & 12.02 & 0.78 & 1.90 & -0.34 \\
\hline \multicolumn{5}{|c|}{ Panel B: Significant UK Banking Instability: 1866, 1878, 1974, 2007-8 } \\
\hline-2 & 12.39 & 0.97 & 1.18 & 0.75 \\
\hline-1 & -0.81 & 0.92 & 1.14 & 0.71 \\
\hline 1866 & -7.96 & 1.14 & 1.44 & 0.85 \\
\hline 1 & -8.93 & 1.30 & 1.63 & 0.98 \\
\hline 2 & -0.139 & 1.18 & 1.47 & 0.90 \\
\hline-2 & 1.25 & 0.75 & 0.86 & 0.63 \\
\hline-1 & 4.62 & 0.92 & 1.11 & 0.72 \\
\hline 1878 & -9.67 & 0.93 & 1.13 & 0.73 \\
\hline 1 & -4.11 & 0.95 & 1.19 & 0.73 \\
\hline 2 & 3.66 & 0.84 & 1.10 & 0.58 \\
\hline-2 & 48.98 & -0.32 & 0.97 & -1.60 \\
\hline-1 & -27.79 & -0.67 & 1.17 & -2.51 \\
\hline 1974 & -62.85 & -1.51 & 2.11 & -5.14 \\
\hline 1 & 154.64 & -2.06 & 0.81 & -4.91 \\
\hline 2 & -17.99 & -1.82 & 0.85 & -4.50 \\
\hline-2 & 5.14 & 0.66 & 1.30 & 0.02 \\
\hline-1 & 16.10 & 0.77 & 1.51 & 0.04 \\
\hline 2007 & -26.87 & 0.96 & 1.70 & 0.22 \\
\hline 2008 & -76.5 & 2.76 & 4.20 & 1.36 \\
\hline 1 & 7.83 & 0.67 & 1.70 & -0.36 \\
\hline 2 & 9.94 & 0.19 & 1.35 & -0.96 \\
\hline
\end{tabular}

Notes: Panel A includes all banking crises discussed in Reinhart and Rogoff (2009). Panel B includes the years 1866, 1878, 1974 and 2007-8; periods in which 10 per cent or more of all banks lost more than 20 per cent of their market value (see Table 2). The corporate bond risk premium over government bonds is further categorised into two subsets of High risk premium 1/2 (highest 50\% of yields) and Low risk premium 1/2 (lowest $50 \%$ of yields).

Sources: See Appendix Table 1. 
Table 7.

Granger causality tests using risk premium sub-samples, 1860-2010.

\begin{tabular}{|c|c|c|c|c|c|c|c|c|c|c|c|c|}
\hline & \multirow[b]{3}{*}{$\begin{array}{c}\text { Dependant } \\
\text { Variable }\end{array}$} & & & & & & & & & & & \\
\hline & & $\begin{array}{c}\text { Bank } \\
\text { Instability }\end{array}$ & $\begin{array}{c}\text { Risk } \\
\text { premium }\end{array}$ & $\begin{array}{c}\text { Equity } \\
\text { returns } \\
(\text { real, \%) }\end{array}$ & $\begin{array}{l}\text { Bank } \\
\text { lending } \\
\text { growth } \\
(\%)\end{array}$ & $\begin{array}{c}\text { GDP } \\
\text { growth } \\
\text { (real, \%) }\end{array}$ & $\begin{array}{l}\text { Money } \\
\text { supply } \\
\text { growth } \\
(\%)\end{array}$ & $\begin{array}{l}\text { Inflation } \\
(\%)\end{array}$ & $\begin{array}{l}\text { Interest } \\
\text { rate } \\
\text { (real, \%) }\end{array}$ & $\begin{array}{l}\text { Exchange } \\
\text { Rate }\end{array}$ & $\begin{array}{l}\text { Public net } \\
\text { debt } \\
\text { growth } \\
(\%)\end{array}$ & $\begin{array}{l}\text { Wheat } \\
\text { price } \\
\text { growth } \\
(\%)\end{array}$ \\
\hline & & (P-Value $)$ & $(P$-Value $)$ & (P-Value $)$ & (P-Value) & (P-Value) & $(P$-Value $)$ & (P-Value) & (P-Value) & (P-Value) & $(P$-Value $)$ & (P-Value) \\
\hline \multicolumn{13}{|l|}{ Panel A: Absolute returns } \\
\hline Risk Premium (Full Sample) & Risk Premium & 0.018 & 0.000 & 0.104 & 0.340 & 0.345 & 0.556 & 0.242 & 0.249 & 0.639 & 0.540 & 0.137 \\
\hline Risk Premium (High Risk 1/2) & Risk Premium & 0.007 & 0.004 & 0.350 & 0.842 & 0.636 & 0.825 & 0.465 & 0.091 & 0.813 & 0.531 & 0.048 \\
\hline Risk Premium (Low Risk 1/2) & Risk Premium & 0.002 & 0.007 & 0.004 & 0.169 & 0.326 & 0.133 & 0.000 & 0.000 & 0.784 & 0.058 & 0.199 \\
\hline \multicolumn{13}{|l|}{ Panel B: Drawdown } \\
\hline Risk Premium (Full Sample) & Risk Premium & 0.020 & 0.000 & 0.777 & 0.344 & 0.507 & 0.197 & 0.189 & 0.334 & 0.946 & 0.150 & 0.085 \\
\hline Risk Premium (High Risk 1/2) & Risk Premium & 0.067 & 0.040 & 0.461 & 0.828 & 0.798 & 0.618 & 0.783 & 0.512 & 0.995 & 0.271 & 0.001 \\
\hline Risk Premium (Low Risk 1/2) & Risk Premium & 0.022 & 0.000 & 0.028 & 0.657 & 0.507 & 0.056 & 0.009 & 0.019 & 0.998 & 0.297 & 0.095 \\
\hline \multicolumn{13}{|c|}{ Standard deviation of returns } \\
\hline Risk Premium (Full Sample) & Risk Premium & 0.153 & 0.000 & 0.459 & 0.348 & 0.565 & 0.360 & 0.166 & 0.181 & 0.749 & 0.529 & 0.100 \\
\hline Risk Premium (High Risk 1/2) & Risk Premium & 0.096 & 0.036 & 0.412 & 0.842 & 0.873 & 0.872 & 0.458 & 0.115 & 0.964 & 0.481 & 0.000 \\
\hline Risk Premium (Low Risk 1/2) & Risk Premium & 0.005 & 0.000 & 0.070 & 0.500 & 0.4351 & 0.068 & 0.000 & 0.0001 & 0.917 & 0.469 & 0.072 \\
\hline \multicolumn{13}{|l|}{ Nominal returns } \\
\hline Risk Premium (Full Sample) & Risk Premium & 0.250 & 0.000 & 0.539 & 0.523 & 0.486 & 0.320 & 0.016 & 0.202 & 0.962 & 0.117 & 0.105 \\
\hline Risk Premium (High Risk 1/2) & Risk Premium & 0.440 & 0.104 & 0.900 & 0.762 & 0.801 & 0.759 & 0.687 & 0.663 & 0.998 & 0.164 & 0.000 \\
\hline Risk Premium (Low Risk 1/2) & Risk Premium & 0.274 & 0.001 & 0.034 & 0.631 & 0.388 & 0.158 & 0.006 & 0.010 & 0.933 & 0.31 & 0.110 \\
\hline
\end{tabular}

Notes: Each row represents the p-values from Granger causality tests following a vector autoregression. Only the results relevant to the risk premium variable are presented here. The exchange rate and both high and low risk premium variables are differenced to ensure stationarity. 


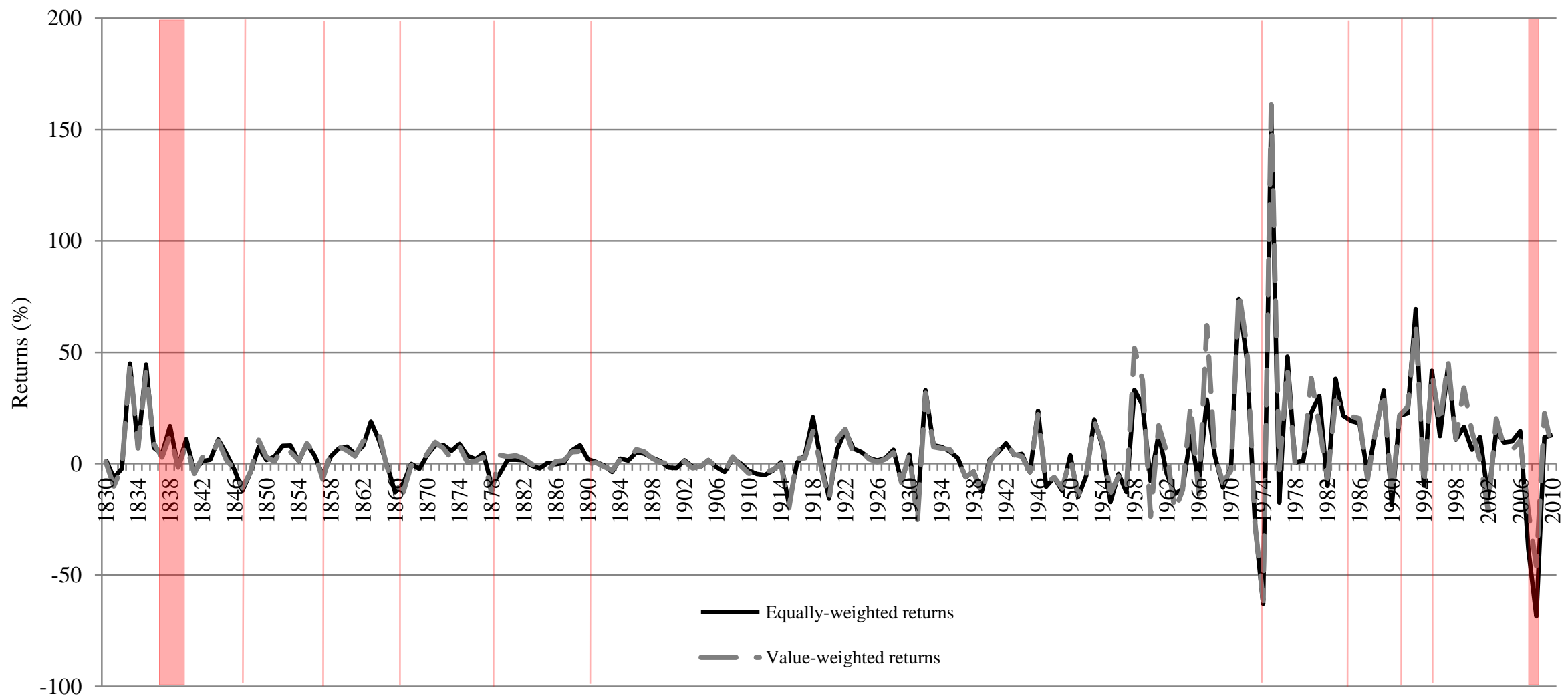

Fig. 1.

British bank returns, 1830-2010.

Notes: The banking crises documented in Reinhart and Rogoff (2009) are highlighted. Failed/nationalised banks are removed from sample at point of failure/nationalisation. Sources: See Appendix Table 1. 


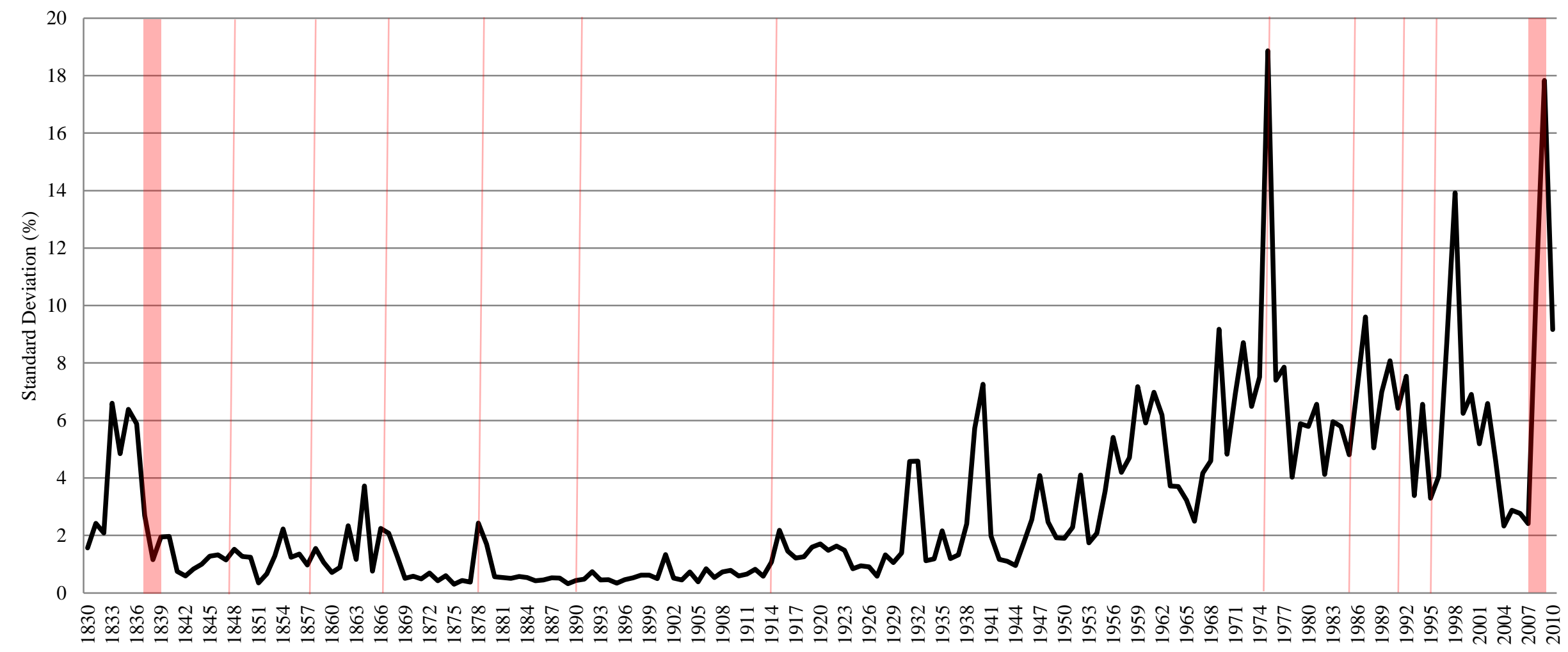

Fig. 2.

Annual volatility of British bank returns, 1830-2010.

Notes: Annual volatility is calculated using the standard deviation of monthly bank returns. The banking crises documented in Reinhart and Rogoff (2009) are highlighted. Sources: See Appendix Table 1. 


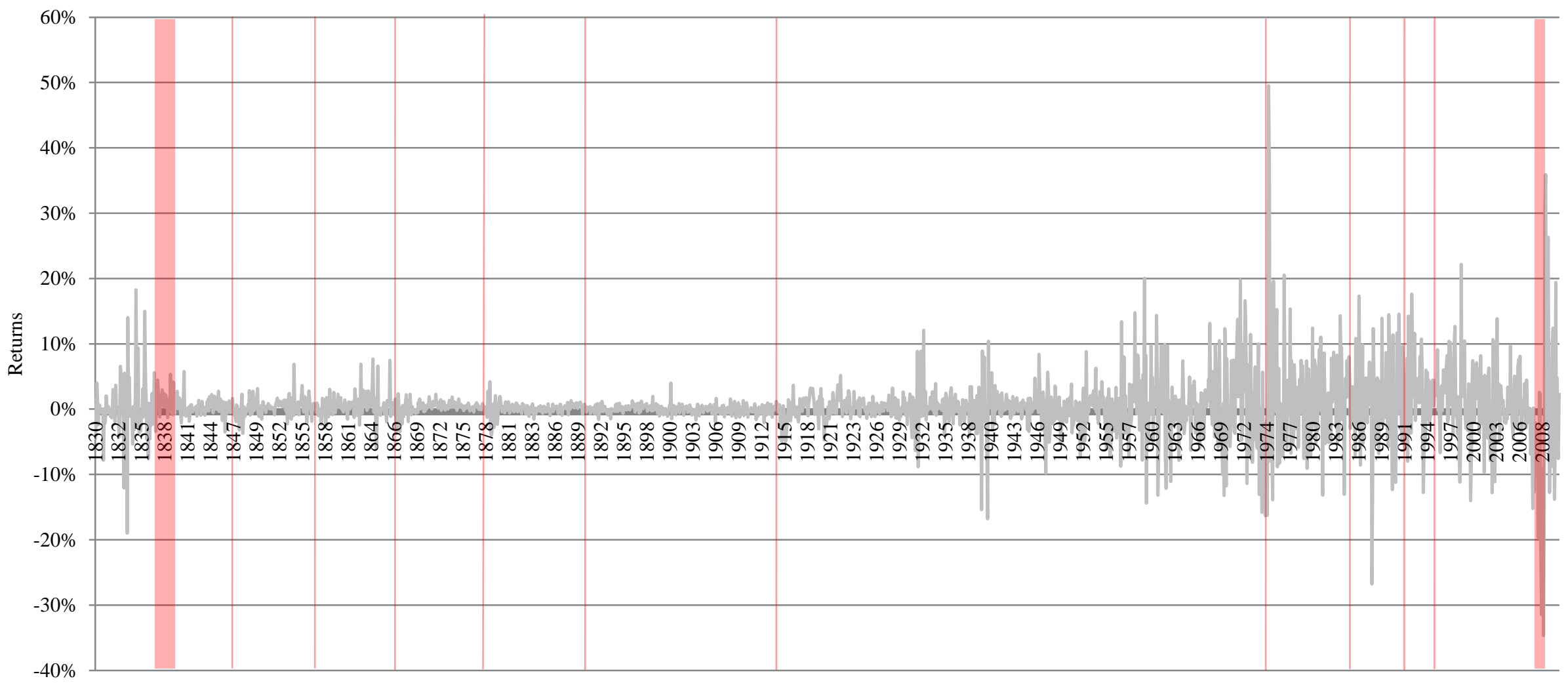

Fig. 3.

Monthly returns of British banks, 1830-2010.

Notes: The banking crises documented in Reinhart and Rogoff (2009) are highlighted. Failed/nationalised banks are removed from sample at point of failure/nationalisation. Sources: See Appendix Table 1. 

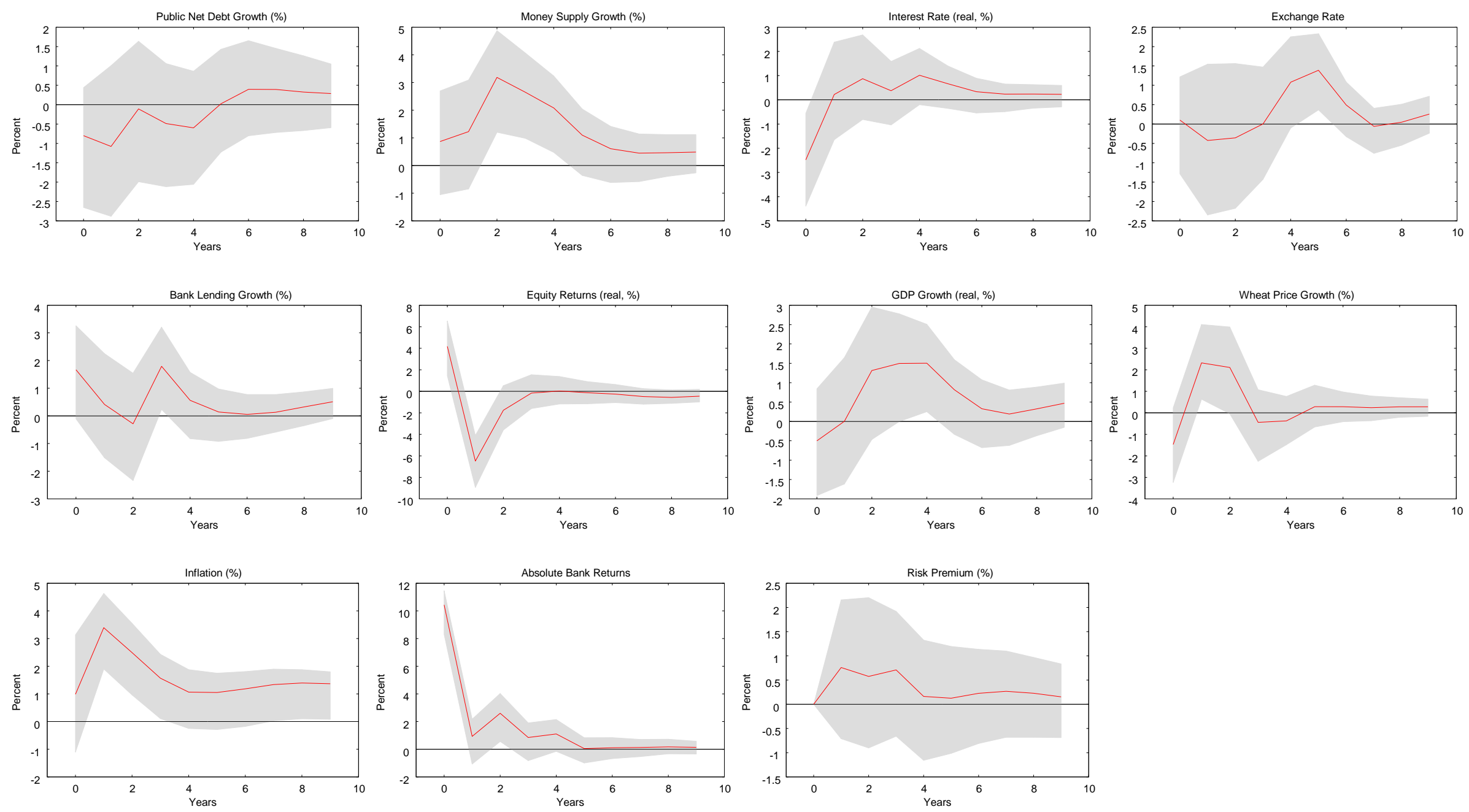

Fig. 4.

Impulse response functions of banking instability (order 1).

Notes: These VAR Cholesky orthogonalized impulse response functions are estimated using annual data from 1860-2010, the ordering of the variables is as shown above. Each function displays the response to a one standard deviation shock in each indicator variable, with bootstrap 90\% confidence intervals. 

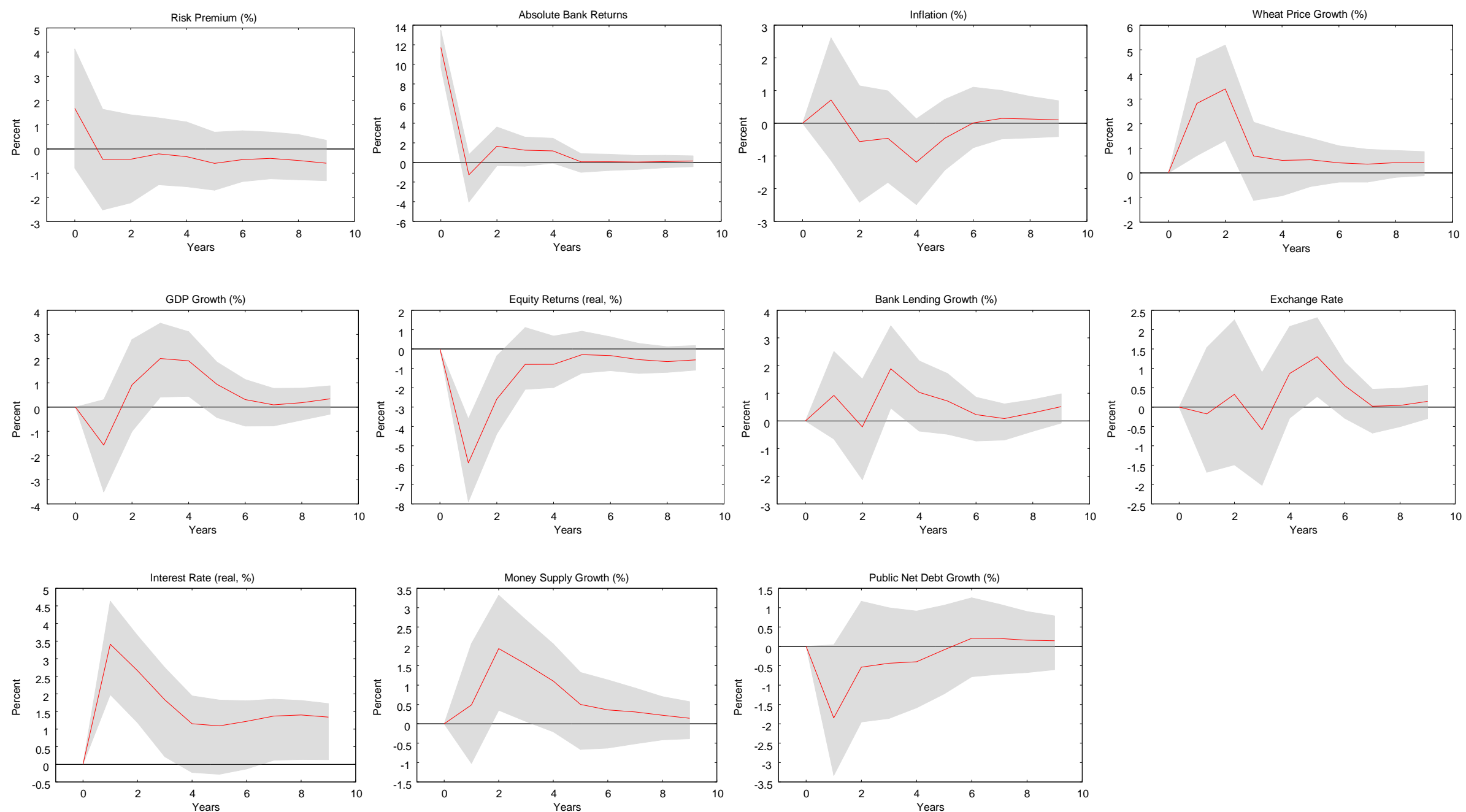

Fig. 5.

Impulse response functions of banking instability (order 2).

Notes: These VAR Cholesky orthogonalized impulse response functions are estimated using annual data from 1860-2010, the ordering of the variables is as shown above. Each function displays the response to a one standard deviation shock in each indicator variable, with bootstrap $90 \%$ confidence intervals. 


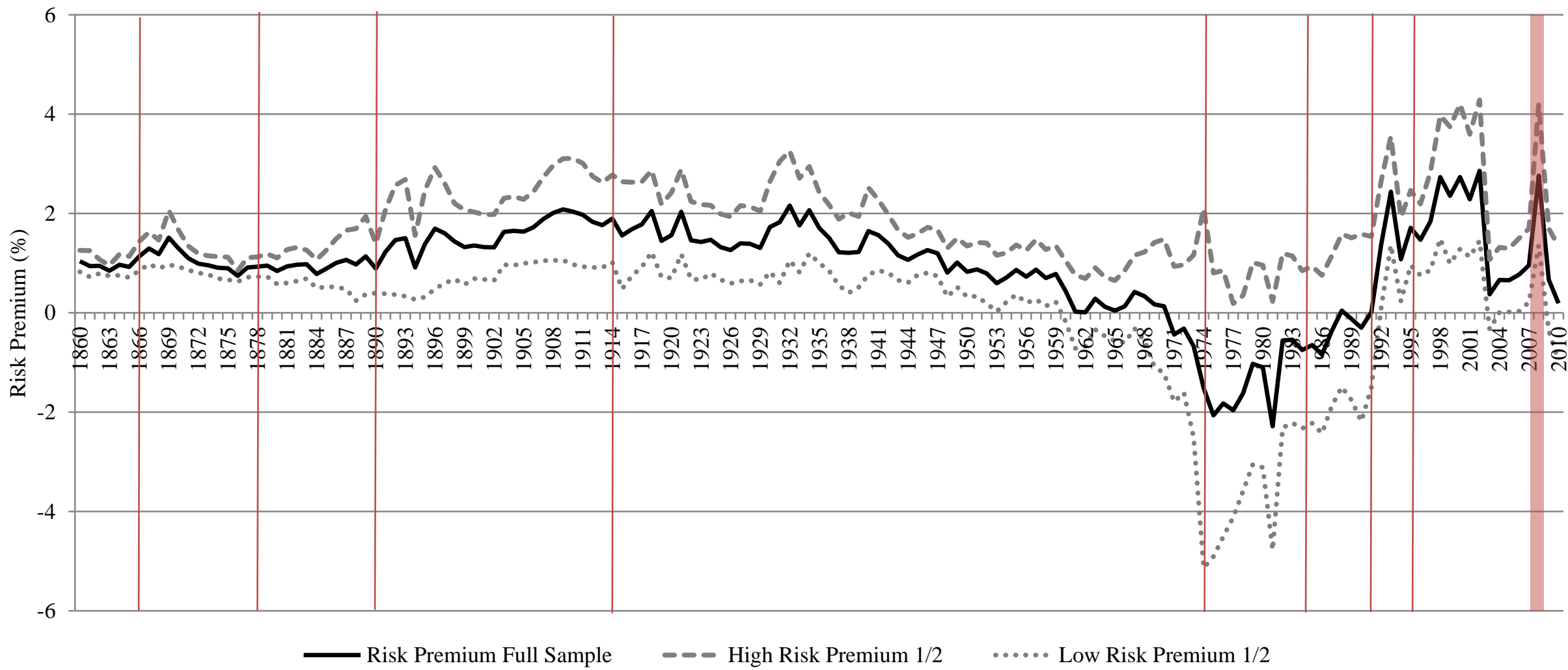

Fig. 6.

UK corporate bond risk premium, 1860-2010.

Notes: The corporate bond risk premium is the excess of current yield on debentures over and above Consols or high-coupon, long-dated government bonds. The corporate bond risk premium over government bonds is further categorised into two subsets of High Risk Premium 1/2 (highest 50\% of yields) and Low Risk Premium 1/2 (lowest 50\% of yields). Highlighted banking crises are those discussed in Reinhart and Rogoff (2009).

Sources: See Appendix Table 1. 
Appendix Table 1 .

Data sources.

\begin{tabular}{|c|c|c|c|}
\hline Data & Year & Variable & Source \\
\hline \multirow{6}{*}{$\begin{array}{l}\text { Bank Share Prices and } \\
\text { Market Capitalisation }\end{array}$} & \multirow[t]{6}{*}{$1830-2010$} & \multirow[t]{6}{*}{ Bank returns } & Course of the Exchange (1830-1868) \\
\hline & & & The Scotsman (1834-1867, 1930-1938) \\
\hline & & & Belfast Newsletter (1830-1868) \\
\hline & & & Investor's Monthly Manual (1869-1929) \\
\hline & & & Banking Almanac and Yearbook (1845-1930) \\
\hline & & & Thomson Reuters Datastream (1965-2010) \\
\hline \multirow[t]{4}{*}{ Money Supply (M3) } & 1834-1869 & \multirow[t]{4}{*}{ M3 growth } & Gregory (1936); Holmes, and Greene (1986)* \\
\hline & 1870-1982 & & Capie and Webber (1985) \\
\hline & 1983-1985 & & BIS Annual Reports (1983-1986) \\
\hline & $1986-2010$ & & Bank of England Interactive Database (2011) \\
\hline Interest Rate & $1830-2010$ & $\begin{array}{l}\text { Real interest } \\
\text { rate }\end{array}$ & Officer (2011) \\
\hline Dollar Exchange Rate & $1830-2010$ & Exchange rate & Officer (2011) \\
\hline GDP & $1830-2010$ & $\begin{array}{l}\text { Real GDP } \\
\text { growth }\end{array}$ & Officer (2011) \\
\hline \multirow[t]{2}{*}{ CPI } & $1830-2003$ & \multirow[t]{2}{*}{ Inflation } & O’Donoghue, et al. (2004) \\
\hline & 2004-2010 & & ONS \\
\hline \multirow[t]{4}{*}{ Equity Returns } & $1825-1870$ & \multirow{4}{*}{$\begin{array}{l}\text { Real equity } \\
\text { returns }\end{array}$} & Acheson et al. (2009) \\
\hline & $1871-1899$ & & Grossman (2002) \\
\hline & $1900-2009$ & & Dimson et al. (2011) \\
\hline & 2010 & & Barclays (2011) \\
\hline \multirow{5}{*}{$\begin{array}{l}\text { Consols/Government } \\
\text { Bonds }\end{array}$} & $1830-1840$ & \multirow[t]{5}{*}{ Risk premium } & Mitchell (1988) \\
\hline & $1840-1871$ & & Course of the Exchange (1840-1871) \\
\hline & $1871-1913$ & & Annual Statistical Abstract for the United Kingdom (1871-1913) \\
\hline & 1914-2009 & & Dimson et al. (2011) \\
\hline & 2010 & & Barclays (2011) \\
\hline \multirow[t]{4}{*}{ Corporate Bond Yield } & $1860-1863$ & \multirow[t]{4}{*}{ Risk premium } & Course of the Exchange (1860-63) \\
\hline & $1864-1929$ & & Investor's Monthly Manual (1864-1929)** \\
\hline & 1930-2002 & & Stock Exchange Daily Official List (1930-2002) \\
\hline & 2003-2010 & & Bloomberg \\
\hline \multirow[t]{2}{*}{ Wheat Price } & $1820-1980$ & \multirow{2}{*}{$\begin{array}{l}\text { Wheat price } \\
\text { growth }\end{array}$} & Mitchell (1988) \\
\hline & $1980-2010$ & & London Gazette (1980-2010) \\
\hline \multirow[t]{2}{*}{ Net Public Debt } & $1830-1950$ & \multirow{2}{*}{$\begin{array}{l}\text { Net public debt } \\
\text { growth }\end{array}$} & Mitchell (1988) \\
\hline & $1951-2010$ & & $\begin{array}{l}\text { National Income and Expenditure (1956-1983), Public Expenditure } \\
\text { Statistical Analyses (1998-2010) }\end{array}$ \\
\hline \multirow[t]{2}{*}{ Housing Prices } & $1900-1945$ & \multirow{2}{*}{$\begin{array}{l}\text { Housing price } \\
\text { growth }\end{array}$} & Liesner (1989) \\
\hline & 1946-2010 & & Department for Communities and Local Govt. (2011) \\
\hline \multirow[t]{3}{*}{ Bank Lending } & $1860-1880$ & \multirow{3}{*}{$\begin{array}{l}\text { Bank lending } \\
\text { growth }\end{array}$} & The Bankers' Magazine (1859-1881)*** \\
\hline & $1881-1962$ & & Sheppard (1971) \\
\hline & $1963-2010$ & & Bank of England Interactive Database (2011) \\
\hline
\end{tabular}

Notes: *Average deposit growth in London and Westminster, London and County and Midland banks used as proxy for money supply growth 18341969. ** Investor's Monthly Manual is made available for the years 1869-1930 by the International Center for Finance (ICF) at Yale University. ***Average lending growth of the twenty largest banks for which balance sheet information is available is used as a proxy for bank lending growth 1860-1881. 
Appendix Table 2.

Granger causality tests of macroeconomic indicators of UK banking instability measured using absolute returns.

\begin{tabular}{|c|c|c|c|c|c|c|c|c|c|c|c|c|c|}
\hline & \multirow[b]{3}{*}{$\begin{array}{c}\text { Dependant } \\
\text { Variable } \\
\end{array}$} & & & & & & & & & & & & \\
\hline & & $\begin{array}{c}\text { Bank } \\
\text { Instability }\end{array}$ & $\begin{array}{c}\text { Risk } \\
\text { premium }\end{array}$ & $\begin{array}{l}\text { Equity } \\
\text { returns } \\
(\text { real, \%) }\end{array}$ & $\begin{array}{l}\text { Bank } \\
\text { lending } \\
\text { growth } \\
(\%)\end{array}$ & $\begin{array}{c}\text { GDP } \\
\text { growth } \\
\text { (real, \%) }\end{array}$ & $\begin{array}{l}\text { Money } \\
\text { supply } \\
\text { growth (\%) }\end{array}$ & $\begin{array}{l}\text { Inflation } \\
(\%)\end{array}$ & $\begin{array}{l}\text { Interest } \\
\text { rate } \\
\text { (real, \%) }\end{array}$ & $\begin{array}{l}\text { Exchange } \\
\text { Rate }\end{array}$ & $\begin{array}{l}\text { Public net } \\
\text { debt } \\
\text { growth } \\
(\%)\end{array}$ & $\begin{array}{l}\text { Wheat } \\
\text { price } \\
\text { growth } \\
(\%)\end{array}$ & $\begin{array}{c}\text { House } \\
\text { price } \\
\text { growth } \\
(\%)\end{array}$ \\
\hline & & (p-value) & (p-value) & (p-value) & (p-value) & (p-value) & (p-value) & (p-value) & (p-value) & (p-value) & (p-value) & (p-value) & (p-value) \\
\hline \multirow{11}{*}{$\begin{array}{l}\text { Panel A: } 1860- \\
\quad 2010\end{array}$} & Bank Instability & 0.047 & 0.581 & 0.023 & 0.010 & 0.899 & 0.021 & 0.002 & 0.000 & 0.298 & 0.029 & 0.146 & \\
\hline & Risk Premium & 0.018 & 0.000 & 0.104 & 0.340 & 0.345 & 0.556 & 0.242 & 0.249 & 0.639 & 0.540 & 0.137 & \\
\hline & GDP & 0.029 & 0.903 & 0.052 & 0.934 & 0.002 & 0.072 & 0.145 & 0.216 & 0.397 & 0.041 & 0.042 & \\
\hline & M3 & 0.059 & 0.399 & 0.252 & 0.018 & 0.000 & 0.000 & 0.241 & 0.398 & 0.000 & 0.003 & 0.059 & \\
\hline & Inflation & 0.020 & 0.027 & 0.006 & 0.003 & 0.001 & 0.151 & 0.000 & 0.001 & 0.000 & 0.000 & 0.094 & \\
\hline & Interest & 0.060 & 0.032 & 0.006 & 0.008 & 0.002 & 0.131 & 0.000 & 0.000 & 0.000 & 0.000 & 0.078 & \\
\hline & Exchange Rate & 0.160 & 0.371 & 0.331 & 0.257 & 0.171 & 0.198 & 0.971 & 0.623 & 0.068 & 0.485 & 0.225 & \\
\hline & Public Debt & 0.157 & 0.193 & 0.050 & 0.004 & 0.456 & 0.280 & 0.337 & 0.188 & 0.005 & 0.000 & 0.129 & \\
\hline & Wheat Price & 0.030 & 0.429 & 0.278 & 0.288 & 0.057 & 0.130 & 0.213 & 0.026 & 0.000 & 0.183 & 0.013 & \\
\hline & Equity & 0.862 & 0.088 & 0.118 & 0.000 & 0.073 & 0.997 & 0.312 & 0.137 & 0.342 & 0.263 & 0.231 & \\
\hline & Lending & 0.131 & 0.028 & 0.402 & 0.939 & 0.119 & 0.031 & 0.277 & 0.458 & 0.201 & 0.221 & 0.565 & \\
\hline \multirow{10}{*}{$\begin{array}{l}\text { Panel B: } 1835- \\
2010\end{array}$} & Bank Instability & 0.041 & & 0.013 & & 0.832 & 0.083 & 0.009 & 0.000 & 0.945 & 0.192 & 0.240 & \\
\hline & Risk Premium & & & & & & & & & & & & \\
\hline & GDP & 0.074 & & 0.017 & & 0.095 & 0.309 & 0.230 & 0.299 & 0.293 & 0.044 & 0.132 & \\
\hline & M3 & 0.094 & & 0.617 & & 0.055 & 0.000 & 0.281 & 0.130 & 0.031 & 0.000 & 0.104 & \\
\hline & Inflation & 0.740 & & 0.750 & & 0.012 & 0.355 & 0.000 & 0.000 & 0.059 & 0.000 & 0.333 & \\
\hline & Interest & 0.763 & & 0.908 & & 0.020 & 0.345 & 0.001 & 0.000 & 0.060 & 0.000 & 0.370 & \\
\hline & Exchange Rate & 0.521 & & 0.550 & & 0.274 & 0.031 & 0.986 & 0.748 & 0.000 & 0.882 & 0.234 & \\
\hline & Public Debt & 0.166 & & 0.048 & & 0.744 & 0.484 & 0.230 & 0.093 & 0.701 & 0.000 & 0.230 & \\
\hline & Wheat Price & 0.179 & & 0.911 & & 0.024 & 0.260 & 0.420 & 0.028 & 0.048 & 0.366 & 0.044 & \\
\hline & Equity & 0.968 & & 0.328 & & 0.218 & 0.937 & 0.023 & 0.019 & 0.152 & 0.832 & 0.162 & \\
\hline
\end{tabular}

Notes: Each row represents the p-values from Granger causality tests. The exchange rate is differenced to ensure stationarity. 
Appendix Table 2 Cont.

Granger causality tests of macroeconomic indicators of UK banking instability measured using absolute returns.

\begin{tabular}{|c|c|c|c|c|c|c|c|c|c|c|c|c|c|}
\hline & \multirow{2}{*}{$\begin{array}{c}\text { Dependant } \\
\text { Variable } \\
\end{array}$} & $\begin{array}{c}\text { Bank } \\
\text { Instability }\end{array}$ & $\begin{array}{c}\text { Risk } \\
\text { premium }\end{array}$ & $\begin{array}{c}\text { Equity } \\
\text { returns } \\
\text { (real, \%) }\end{array}$ & $\begin{array}{c}\text { Bank } \\
\text { lending } \\
\text { growth } \\
(\%)\end{array}$ & $\begin{array}{c}\text { GDP } \\
\text { growth } \\
\text { (real, \%) }\end{array}$ & $\begin{array}{c}\text { Money } \\
\text { supply } \\
\text { growth (\%) }\end{array}$ & $\begin{array}{l}\text { Inflation } \\
\quad \%)\end{array}$ & $\begin{array}{c}\text { Interest } \\
\text { rate } \\
\text { (real, \%) }\end{array}$ & $\begin{array}{l}\text { Exchange } \\
\text { Rate }\end{array}$ & $\begin{array}{l}\text { Public net } \\
\text { debt } \\
\text { growth } \\
(\%)\end{array}$ & $\begin{array}{l}\text { Wheat } \\
\text { price } \\
\text { growth } \\
(\%)\end{array}$ & $\begin{array}{l}\text { House } \\
\text { price } \\
\text { growth }(\%)\end{array}$ \\
\hline & & (p-value) & (p-value) & (p-value) & (p-value) & (p-value) & (p-value) & (p-value) & (p-value) & (p-value) & (p-value) & (p-value) & (p-value) \\
\hline \multirow{12}{*}{$\begin{array}{c}\text { Panel C: 1901- } \\
2010\end{array}$} & Bank Instability & 0.039 & 0.845 & 0.035 & 0.017 & 0.732 & 0.088 & 0.009 & 0.000 & 0.754 & 0.036 & 0.149 & 0.168 \\
\hline & Risk Premium & 0.048 & 0.000 & 0.255 & 0.300 & 0.524 & 0.331 & 0.486 & 0.436 & 0.991 & 0.561 & 0.133 & 0.278 \\
\hline & GDP & 0.010 & 0.651 & 0.100 & 0.958 & 0.001 & 0.096 & 0.027 & 0.053 & 0.761 & 0.071 & 0.076 & 0.062 \\
\hline & M3 & 0.023 & 0.184 & 0.176 & 0.000 & 0.001 & 0.000 & 0.086 & 0.115 & 0.059 & 0.005 & 0.231 & 0.291 \\
\hline & Inflation & 0.087 & 0.030 & 0.005 & 0.000 & 0.000 & 0.135 & 0.000 & 0.005 & 0.254 & 0.000 & 0.097 & 0.784 \\
\hline & Interest & 0.114 & 0.036 & 0.002 & 0.000 & 0.001 & 0.066 & 0.001 & 0.000 & 0.262 & 0.000 & 0.076 & 0.881 \\
\hline & Exchange Rate & 0.090 & 0.450 & 0.052 & 0.001 & 0.073 & 0.259 & 0.761 & 0.188 & 0.000 & 0.690 & 0.276 & 0.044 \\
\hline & Public Debt & 0.223 & 0.295 & 0.117 & 0.012 & 0.949 & 0.306 & 0.748 & 0.640 & 0.712 & 0.000 & 0.191 & 0.516 \\
\hline & Wheat Price & 0.025 & 0.262 & 0.193 & 0.231 & 0.109 & 0.367 & 0.046 & 0.001 & 0.722 & 0.159 & 0.012 & 0.448 \\
\hline & Equity & 0.574 & 0.079 & 0.018 & 0.002 & 0.067 & 1.000 & 0.073 & 0.031 & 0.546 & 0.103 & 0.269 & 0.229 \\
\hline & Lending & 0.260 & 0.045 & 0.693 & 0.795 & 0.120 & 0.069 & 0.053 & 0.115 & 0.010 & 0.151 & 0.481 & 0.110 \\
\hline & House Prices & 0.314 & 0.678 & 0.599 & 0.000 & 0.134 & 0.018 & 0.011 & 0.016 & 0.467 & 0.380 & 0.011 & 0.016 \\
\hline
\end{tabular}

Notes: Each row represents the p-values from Granger causality tests. The exchange rate is differenced to ensure stationarity. 
Appendix Table 3.

Granger causality tests of macroeconomic indicators of UK banking instability measured using drawdown.

\begin{tabular}{|c|c|c|c|c|c|c|c|c|c|c|c|c|c|}
\hline & \multirow{3}{*}{$\begin{array}{c}\text { Dependant } \\
\text { Variable } \\
\end{array}$} & & & & & & & & & & & & \\
\hline & & $\begin{array}{c}\text { Bank } \\
\text { Instability }\end{array}$ & $\begin{array}{c}\text { Risk } \\
\text { premium }\end{array}$ & $\begin{array}{l}\text { Equity } \\
\text { returns } \\
\text { (real, \%) }\end{array}$ & $\begin{array}{c}\text { Bank } \\
\text { lending } \\
\text { growth } \\
(\%)\end{array}$ & $\begin{array}{c}\text { GDP } \\
\text { growth } \\
\text { (real, \%) }\end{array}$ & $\begin{array}{l}\text { Money } \\
\text { supply } \\
\text { growth (\%) }\end{array}$ & $\begin{array}{c}\text { Inflation } \\
(\%)\end{array}$ & $\begin{array}{c}\text { Interest } \\
\text { rate } \\
\text { (real, \%) }\end{array}$ & $\begin{array}{c}\text { Exchange } \\
\text { Rate }\end{array}$ & $\begin{array}{l}\text { Public net } \\
\text { debt } \\
\text { growth (\%) }\end{array}$ & $\begin{array}{l}\text { Wheat } \\
\text { price } \\
\text { growth (\%) }\end{array}$ & $\begin{array}{c}\text { House } \\
\text { price } \\
\text { growth } \\
(\%)\end{array}$ \\
\hline & & (p-value) & (p-value) & (p-value) & (p-value) & (p-value) & (p-value) & (p-value) & (p-value) & (p-value) & (p-value) & (p-value) & (p-value) \\
\hline \multirow{11}{*}{$\begin{array}{l}\text { Panel A: } 1860- \\
2010\end{array}$} & Bank Instability & 0.001 & 0.770 & 0.083 & 0.016 & 0.638 & 0.919 & 0.008 & 0.072 & 0.043 & 0.681 & 0.376 & \\
\hline & Risk Premium & 0.020 & 0.000 & 0.777 & 0.344 & 0.507 & 0.197 & 0.189 & 0.334 & 0.946 & 0.150 & 0.085 & \\
\hline & GDP & 0.663 & 0.960 & 0.078 & 0.926 & 0.008 & 0.087 & 0.005 & 0.031 & 0.443 & 0.043 & 0.047 & \\
\hline & M3 & 0.093 & 0.534 & 0.009 & 0.023 & 0.000 & 0.000 & 0.141 & 0.188 & 0.000 & 0.022 & 0.139 & \\
\hline & Inflation & 0.067 & 0.100 & 0.112 & 0.003 & 0.002 & 0.082 & 0.000 & 0.002 & 0.000 & 0.000 & 0.088 & \\
\hline & Interest & 0.065 & 0.099 & 0.119 & 0.008 & 0.005 & 0.058 & 0.000 & 0.000 & 0.000 & 0.000 & 0.084 & \\
\hline & fExchange Rate & 0.133 & 0.492 & 0.081 & 0.298 & 0.215 & 0.260 & 0.842 & 0.947 & 0.053 & 0.777 & 0.328 & \\
\hline & Public Debt & 0.039 & 0.151 & 0.074 & 0.016 & 0.680 & 0.128 & 0.009 & 0.001 & 0.005 & 0.000 & 0.039 & \\
\hline & Wheat Price & 0.219 & 0.869 & 0.448 & 0.312 & 0.160 & 0.156 & 0.968 & 0.104 & 0.002 & 0.117 & 0.016 & \\
\hline & Equity & 0.012 & 0.616 & 0.117 & 0.001 & 0.090 & 0.309 & 0.031 & 0.006 & 0.131 & 0.177 & 0.144 & \\
\hline & Lending & 0.236 & 0.087 & 0.742 & 0.915 & 0.093 & 0.031 & 0.554 & 0.788 & 0.244 & 0.245 & 0.583 & \\
\hline \multirow{10}{*}{$\begin{array}{c}\text { Panel B: } 1835- \\
2010\end{array}$} & Bank Instability & 0.000 & & 0.118 & & 0.639 & 0.160 & 0.049 & 0.069 & 0.266 & 0.914 & 0.382 & \\
\hline & Risk Premium & & & & & & & & & & & & \\
\hline & GDP & 0.840 & & 0.193 & & 0.114 & 0.446 & 0.047 & 0.203 & 0.289 & 0.034 & 0.057 & \\
\hline & M3 & 0.048 & & 0.641 & & 0.034 & 0.000 & 0.414 & 0.037 & 0.025 & 0.001 & 0.182 & \\
\hline & Inflation & 0.056 & & 0.958 & & 0.009 & 0.210 & 0.000 & 0.000 & 0.052 & 0.000 & 0.352 & \\
\hline & Interest & 0.029 & & 0.960 & & 0.014 & 0.181 & 0.003 & 0.000 & 0.054 & 0.000 & 0.398 & \\
\hline & Exchange Rate & 0.077 & & 0.441 & & 0.289 & 0.109 & 0.476 & 0.715 & 0.001 & 0.671 & 0.212 & \\
\hline & Public Debt & 0.065 & & 0.025 & & 0.785 & 0.848 & 0.013 & 0.008 & 0.438 & 0.000 & 0.157 & \\
\hline & Wheat Price & 0.360 & & 0.537 & & 0.047 & 0.368 & 0.540 & 0.185 & 0.049 & 0.301 & 0.052 & \\
\hline & Equity & 0.004 & & 0.037 & & 0.384 & 0.257 & 0.012 & 0.002 & 0.164 & 0.828 & 0.158 & \\
\hline
\end{tabular}

Notes: Each row represents the p-values from Granger causality tests. The exchange rate is differenced to ensure stationarity. 
Appendix Table 3 cont.

Granger causality tests of macroeconomic indicators of UK banking instability measured using drawdown.

\begin{tabular}{|c|c|c|c|c|c|c|c|c|c|c|c|c|c|}
\hline & \multirow{2}{*}{$\begin{array}{c}\text { Dependant } \\
\text { Variable }\end{array}$} & $\begin{array}{c}\text { Bank } \\
\text { Instability }\end{array}$ & $\begin{array}{c}\text { Risk } \\
\text { premium }\end{array}$ & $\begin{array}{l}\text { Equity } \\
\text { returns } \\
(\text { real, \%) }\end{array}$ & $\begin{array}{c}\text { Bank } \\
\text { lending } \\
\text { growth } \\
(\%)\end{array}$ & $\begin{array}{c}\text { GDP } \\
\text { growth } \\
\text { (real, \%) }\end{array}$ & $\begin{array}{c}\text { Money } \\
\text { supply } \\
\text { growth (\%) }\end{array}$ & $\begin{array}{l}\text { Inflation } \\
(\%)\end{array}$ & $\begin{array}{l}\text { Interest } \\
\text { rate } \\
\text { (real, \%) }\end{array}$ & $\begin{array}{c}\text { Exchange } \\
\text { Rate }\end{array}$ & $\begin{array}{l}\text { Public net } \\
\text { debt } \\
\text { growth }(\%)\end{array}$ & $\begin{array}{c}\text { Wheat } \\
\text { price } \\
\text { growth }(\%)\end{array}$ & $\begin{array}{c}\text { House } \\
\text { price } \\
\text { growth } \\
(\%)\end{array}$ \\
\hline & & (p-value) & (p-value) & (p-value) & (p-value) & (p-value) & (p-value) & (p-value) & (p-value) & (p-value) & (p-value) & (p-value) & (p-value) \\
\hline \multirow{12}{*}{$\begin{array}{c}\text { Panel C: 1901- } \\
2010\end{array}$} & Bank Instability & 0.006 & 0.651 & 0.066 & 0.241 & 0.241 & 0.729 & 0.000 & 0.015 & 0.197 & 0.621 & 0.360 & 0.623 \\
\hline & Risk Premium & 0.000 & 0.000 & 0.852 & 0.382 & 0.619 & 0.079 & 0.353 & 0.493 & 0.830 & 0.282 & 0.061 & 0.008 \\
\hline & GDP & 0.658 & 0.729 & 0.081 & 0.788 & 0.003 & 0.080 & 0.037 & 0.077 & 0.638 & 0.066 & 0.102 & 0.023 \\
\hline & M3 & 0.050 & 0.179 & 0.011 & 0.000 & 0.000 & 0.000 & 0.396 & 0.436 & 0.062 & 0.036 & 0.464 & 0.710 \\
\hline & Inflation & 0.289 & 0.113 & 0.042 & 0.000 & 0.000 & 0.094 & 0.001 & 0.011 & 0.126 & 0.000 & 0.120 & 0.429 \\
\hline & Interest & 0.274 & 0.145 & 0.007 & 0.000 & 0.001 & 0.043 & 0.002 & 0.000 & 0.118 & 0.000 & 0.109 & 0.870 \\
\hline & Exchange Rate & 0.163 & 0.610 & 0.010 & 0.001 & 0.413 & 0.181 & 0.739 & 0.375 & 0.000 & 0.309 & 0.153 & 0.048 \\
\hline & Public Debt & 0.048 & 0.148 & 0.147 & 0.086 & 0.870 & 0.117 & 0.091 & 0.001 & 0.678 & 0.000 & 0.061 & 0.521 \\
\hline & Wheat Price & 0.280 & 0.645 & 0.381 & 0.381 & 0.224 & 0.515 & 0.254 & 0.002 & 0.201 & 0.110 & 0.016 & 0.095 \\
\hline & Equity & 0.025 & 0.687 & 0.062 & 0.009 & 0.087 & 0.425 & 0.001 & 0.000 & 0.499 & 0.095 & 0.168 & 0.268 \\
\hline & Lending & 0.549 & 0.144 & 0.875 & 0.816 & 0.089 & 0.118 & 0.057 & 0.152 & 0.010 & 0.213 & 0.395 & 0.181 \\
\hline & House Prices & 0.275 & 0.961 & 0.531 & 0.000 & 0.378 & 0.023 & 0.003 & 0.002 & 0.502 & 0.350 & 0.007 & 0.025 \\
\hline
\end{tabular}

Notes: Each row represents the p-values from Granger causality tests. The exchange rate is differenced to ensure stationarity. 
Appendix Table 4.

Granger causality tests of macroeconomic indicators of UK banking instability measured using nominal returns.

\begin{tabular}{|c|c|c|c|c|c|c|c|c|c|c|c|c|c|}
\hline & \multirow{3}{*}{$\begin{array}{c}\text { Dependant } \\
\text { Variable } \\
\end{array}$} & & & & & & & & & & & & \\
\hline & & $\begin{array}{c}\text { Bank } \\
\text { Instability }\end{array}$ & $\begin{array}{c}\text { Risk } \\
\text { premium }\end{array}$ & $\begin{array}{l}\text { Equity } \\
\text { returns } \\
\text { (real, \%) }\end{array}$ & $\begin{array}{l}\text { Bank } \\
\text { lending } \\
\text { growth } \\
(\%)\end{array}$ & $\begin{array}{c}\text { GDP } \\
\text { growth } \\
\text { (real, \%) }\end{array}$ & $\begin{array}{c}\text { Money } \\
\text { supply } \\
\text { growth (\%) }\end{array}$ & $\begin{array}{l}\text { Inflation } \\
(\%)\end{array}$ & $\begin{array}{l}\text { Interest } \\
\text { rate } \\
\text { (real, \%) }\end{array}$ & $\begin{array}{l}\text { Exchange } \\
\text { Rate }\end{array}$ & $\begin{array}{l}\text { Public net } \\
\text { debt } \\
\text { growth } \\
(\%)\end{array}$ & $\begin{array}{l}\text { Wheat price } \\
\text { growth (\%) }\end{array}$ & $\begin{array}{c}\text { House } \\
\text { price } \\
\text { growth } \\
(\%)\end{array}$ \\
\hline & & (p-value) & (p-value) & (p-value) & (p-value) & (p-value) & (p-value) & (p-value) & (p-value) & (p-value) & (p-value) & (p-value) & (p-value) \\
\hline \multirow{11}{*}{$\begin{array}{l}\text { Panel A: } 1860- \\
2010\end{array}$} & Bank Instability & 0.473 & 0.196 & 0.167 & 0.017 & 0.659 & 0.888 & 0.000 & 0.001 & 0.075 & 0.139 & 0.151 & \\
\hline & Risk Premium & 0.250 & 0.000 & 0.539 & 0.523 & 0.486 & 0.320 & 0.016 & 0.202 & 0.962 & 0.117 & 0.105 & \\
\hline & GDP & 0.725 & 0.966 & 0.195 & 0.898 & 0.061 & 0.074 & 0.060 & 0.061 & 0.462 & 0.049 & 0.042 & \\
\hline & M3 & 0.035 & 0.152 & 0.062 & 0.011 & 0.000 & 0.000 & 0.633 & 0.499 & 0.000 & 0.004 & 0.202 & \\
\hline & Inflation & 0.100 & 0.201 & 0.033 & 0.006 & 0.002 & 0.265 & 0.000 & 0.001 & 0.000 & 0.000 & 0.071 & \\
\hline & Interest & 0.091 & 0.209 & 0.043 & 0.013 & 0.005 & 0.228 & 0.001 & 0.000 & 0.000 & 0.000 & 0.057 & \\
\hline & Exchange Rate & 0.438 & 0.567 & 0.376 & 0.260 & 0.236 & 0.266 & 0.768 & 0.980 & 0.058 & 0.945 & 0.319 & \\
\hline & Public Debt & 0.207 & 0.195 & 0.445 & 0.019 & 0.531 & 0.153 & 0.015 & 0.004 & 0.006 & 0.000 & 0.074 & \\
\hline & Wheat Price & 0.850 & 0.906 & 0.767 & 0.314 & 0.134 & 0.158 & 0.937 & 0.173 & 0.002 & 0.091 & 0.017 & \\
\hline & Equity & 0.174 & 0.265 & 0.617 & 0.001 & 0.036 & 0.642 & 0.012 & 0.009 & 0.130 & 0.127 & 0.132 & \\
\hline & Lending & 0.191 & 0.035 & 0.963 & 0.911 & 0.107 & 0.048 & 0.661 & 0.759 & 0.277 & 0.181 & 0.597 & \\
\hline \multirow{10}{*}{$\begin{array}{l}\text { Panel B: } 1834- \\
\quad 2010\end{array}$} & Bank Instability & 0.591 & & 0.165 & & 0.874 & 0.358 & 0.000 & 0.001 & 0.174 & 0.494 & 0.253 & \\
\hline & Risk Premium & & & & & & & & & & & & \\
\hline & GDP & 0.883 & & 0.247 & & 0.120 & 0.328 & 0.106 & 0.209 & 0.323 & 0.037 & 0.064 & \\
\hline & M3 & 0.354 & & 0.933 & & 0.050 & 0.000 & 0.573 & 0.103 & 0.055 & 0.000 & 0.266 & \\
\hline & Inflation & 0.142 & & 0.339 & & 0.011 & 0.361 & 0.000 & 0.000 & 0.058 & 0.000 & 0.285 & \\
\hline & Interest & 0.077 & & 0.498 & & 0.018 & 0.339 & 0.006 & 0.000 & 0.061 & 0.000 & 0.331 & \\
\hline & Exchange Rate & 0.147 & & 0.376 & & 0.328 & 0.079 & 0.252 & 0.909 & 0.000 & 0.620 & 0.186 & \\
\hline & Public Debt & 0.130 & & 0.272 & & 0.894 & 0.678 & 0.087 & 0.022 & 0.726 & 0.000 & 0.178 & \\
\hline & Wheat Price & 0.894 & & 0.863 & & 0.049 & 0.228 & 0.370 & 0.287 & 0.040 & 0.292 & 0.062 & \\
\hline & Equity & 0.144 & & 0.845 & & 0.191 & 0.706 & 0.001 & 0.002 & 0.154 & 0.719 & 0.216 & \\
\hline
\end{tabular}

Notes: Each row represents the p-values from Granger causality tests. The exchange rate is differenced to ensure stationarity. 
Appendix Table 4 cont

Granger causality tests of macroeconomic indicators of UK banking instability measured using nominal returns.

\begin{tabular}{|c|c|c|c|c|c|c|c|c|c|c|c|c|c|}
\hline & \multirow{2}{*}{$\begin{array}{c}\text { Dependant } \\
\text { Variable }\end{array}$} & $\begin{array}{c}\text { Bank } \\
\text { Instability }\end{array}$ & $\begin{array}{c}\text { Risk } \\
\text { premium }\end{array}$ & $\begin{array}{c}\text { Equity } \\
\text { returns } \\
\text { (real, \%) }\end{array}$ & $\begin{array}{c}\text { Bank } \\
\text { lending } \\
\text { growth } \\
(\%)\end{array}$ & $\begin{array}{c}\text { GDP } \\
\text { growth } \\
\text { (real, \%) }\end{array}$ & $\begin{array}{c}\text { Money } \\
\text { supply } \\
\text { growth } \\
(\%)\end{array}$ & $\begin{array}{l}\text { Inflation } \\
\quad(\%)\end{array}$ & $\begin{array}{c}\text { Interest } \\
\text { rate (real, } \\
\% \text { ) }\end{array}$ & Exchange Rate & $\begin{array}{l}\text { Public net } \\
\text { debt } \\
\text { growth }(\%)\end{array}$ & $\begin{array}{l}\text { Wheat } \\
\text { price } \\
\text { growth }(\%)\end{array}$ & $\begin{array}{l}\text { House price } \\
\text { growth }(\%)\end{array}$ \\
\hline & & (p-value) & (p-value) & (p-value) & (p-value) & (p-value) & (p-value) & (p-value) & (p-value) & (p-value) & (p-value) & (p-value) & (p-value) \\
\hline \multirow{12}{*}{$\begin{array}{c}\text { Panel C: } 1901- \\
2010\end{array}$} & Bank Instability & 0.567 & 0.043 & 0.146 & 0.049 & 0.416 & 0.997 & 0.000 & 0.000 & 0.645 & 0.124 & 0.086 & 0.556 \\
\hline & Risk Premium & 0.027 & 0.000 & 0.155 & 0.626 & 0.660 & 0.138 & 0.051 & 0.439 & 0.742 & 0.134 & 0.041 & 0.009 \\
\hline & GDP & 0.860 & 0.737 & 0.560 & 0.863 & 0.003 & 0.121 & 0.065 & 0.109 & 0.623 & 0.080 & 0.081 & 0.050 \\
\hline & M3 & 0.009 & 0.040 & 0.013 & 0.000 & 0.000 & 0.000 & 0.817 & 0.869 & 0.032 & 0.009 & 0.591 & 0.642 \\
\hline & Inflation & 0.427 & 0.103 & 0.103 & 0.000 & 0.000 & 0.229 & 0.000 & 0.009 & 0.077 & 0.000 & 0.086 & 0.542 \\
\hline & Interest & 0.482 & 0.098 & 0.072 & 0.000 & 0.001 & 0.127 & 0.005 & 0.000 & 0.078 & 0.000 & 0.068 & 0.899 \\
\hline & Exchange Rate & 0.481 & 0.646 & 0.183 & 0.000 & 0.231 & 0.141 & 0.983 & 0.443 & 0.000 & 0.406 & 0.186 & 0.051 \\
\hline & Public Debt & 0.219 & 0.266 & 0.400 & 0.110 & 0.957 & 0.209 & 0.556 & 0.180 & 0.871 & 0.000 & 0.127 & 0.702 \\
\hline & Wheat Price & 0.980 & 0.692 & 0.827 & 0.278 & 0.180 & 0.419 & 0.395 & 0.003 & 0.227 & 0.101 & 0.020 & 0.220 \\
\hline & Equity & 0.314 & 0.195 & 0.342 & 0.005 & 0.050 & 0.918 & 0.008 & 0.004 & 0.482 & 0.091 & 0.141 & 0.366 \\
\hline & Lending & 0.398 & 0.055 & 0.979 & 0.768 & 0.094 & 0.130 & 0.166 & 0.250 & 0.010 & 0.162 & 0.397 & 0.221 \\
\hline & House Prices & 0.409 & 0.683 & 0.492 & 0.000 & 0.330 & 0.031 & 0.003 & 0.004 & 0.401 & 0.237 & 0.008 & 0.053 \\
\hline
\end{tabular}

Notes: Each row represents the p-values from Granger causality tests. The exchange rate is differenced to ensure stationarity. 
Appendix Table 5 .

Granger causality tests of macroeconomic indicators of UK banking instability measured using standard deviation of returns.

\begin{tabular}{|c|c|c|c|c|c|c|c|c|c|c|c|c|c|}
\hline & \multirow{3}{*}{$\begin{array}{c}\text { Dependant } \\
\text { Variable }\end{array}$} & & & & & & & & & & & & \\
\hline & & $\begin{array}{c}\text { Bank } \\
\text { Instability }\end{array}$ & $\begin{array}{c}\text { Risk } \\
\text { premium }\end{array}$ & $\begin{array}{l}\text { Equity } \\
\text { returns } \\
(\text { real, \%) }\end{array}$ & $\begin{array}{c}\text { Bank } \\
\text { lending } \\
\text { growth } \\
(\%)\end{array}$ & $\begin{array}{c}\text { GDP } \\
\text { growth } \\
\text { (real, \%) }\end{array}$ & $\begin{array}{l}\text { Money } \\
\text { supply } \\
\text { growth } \\
(\%)\end{array}$ & $\begin{array}{l}\text { Inflation } \\
(\%)\end{array}$ & $\begin{array}{l}\text { Interest } \\
\text { rate } \\
(\text { real, \%) }\end{array}$ & Exchange Rate & $\begin{array}{l}\text { Public net } \\
\text { debt } \\
\text { growth } \\
(\%)\end{array}$ & $\begin{array}{l}\text { Wheat } \\
\text { price } \\
\text { growth }(\%)\end{array}$ & $\begin{array}{c}\text { House } \\
\text { price } \\
\text { growth } \\
(\%)\end{array}$ \\
\hline & & (p-value) & (p-value) & (p-value) & (p-value) & (p-value) & (p-value) & (p-value) & (p-value) & (p-value) & (p-value) & (p-value) & (p-value) \\
\hline \multirow{11}{*}{$\begin{array}{l}\text { Panel A: } 1860- \\
2010\end{array}$} & Bank Instability & 0.000 & 0.100 & 0.470 & 0.039 & 0.574 & 0.044 & 0.003 & 0.000 & 0.016 & 0.336 & 0.086 & \\
\hline & Risk Premium & 0.153 & 0.000 & 0.459 & 0.348 & 0.565 & 0.360 & 0.166 & 0.181 & 0.749 & 0.529 & 0.100 & \\
\hline & GDP & 0.004 & 0.735 & 0.075 & 0.863 & 0.010 & 0.063 & 0.366 & 0.603 & 0.448 & 0.070 & 0.059 & \\
\hline & M3 & 0.903 & 0.527 & 0.066 & 0.035 & 0.001 & 0.000 & 0.486 & 0.530 & 0.000 & 0.020 & 0.092 & \\
\hline & Inflation & 0.066 & 0.022 & 0.028 & 0.006 & 0.001 & 0.249 & 0.000 & 0.001 & 0.001 & 0.000 & 0.099 & \\
\hline & Interest & 0.068 & 0.020 & 0.037 & 0.013 & 0.004 & 0.213 & 0.000 & 0.000 & 0.001 & 0.000 & 0.072 & \\
\hline & Exchange Rate & 0.130 & 0.356 & 0.514 & 0.307 & 0.222 & 0.222 & 0.862 & 0.973 & 0.030 & 0.587 & 0.504 & \\
\hline & Public Debt & 0.128 & 0.162 & 0.119 & 0.004 & 0.486 & 0.173 & 0.238 & 0.164 & 0.004 & 0.000 & 0.028 & \\
\hline & Wheat Price & 0.006 & 0.409 & 0.596 & 0.276 & 0.166 & 0.203 & 0.214 & 0.015 & 0.000 & 0.182 & 0.031 & \\
\hline & Equity & 0.784 & 0.098 & 0.129 & 0.001 & 0.062 & 0.985 & 0.336 & 0.176 & 0.354 & 0.206 & 0.146 & \\
\hline & Lending & 0.021 & 0.033 & 0.341 & 0.926 & 0.135 & 0.027 & 0.644 & 0.624 & 0.223 & 0.149 & 0.415 & \\
\hline \multirow{10}{*}{$\begin{array}{l}\text { Panel B: } 1834- \\
2010\end{array}$} & Bank Instability & 0.000 & & 0.486 & & 0.512 & 0.752 & 0.031 & 0.000 & 0.174 & 0.093 & 0.063 & \\
\hline & Risk Premium & & & & & & & & & & & & \\
\hline & GDP & 0.018 & & 0.051 & & 0.146 & 0.250 & 0.291 & 0.386 & 0.328 & 0.074 & 0.119 & \\
\hline & M3 & 0.262 & & 0.054 & & 0.070 & 0.000 & 0.570 & 0.194 & 0.128 & 0.002 & 0.268 & \\
\hline & Inflation & 0.293 & & 0.582 & & 0.010 & 0.381 & 0.000 & 0.000 & 0.047 & 0.000 & 0.458 & \\
\hline & Interest & 0.359 & & 0.818 & & 0.018 & 0.374 & 0.004 & 0.000 & 0.048 & 0.000 & 0.513 & \\
\hline & Exchange Rate & 0.242 & & 0.600 & & 0.378 & 0.051 & 0.700 & 0.946 & 0.000 & 0.940 & 0.436 & \\
\hline & Public Debt & 0.154 & & 0.111 & & 0.891 & 0.556 & 0.196 & 0.112 & 0.876 & 0.000 & 0.116 & \\
\hline & Wheat Price & 0.010 & & 0.628 & & 0.036 & 0.260 & 0.439 & 0.038 & 0.006 & 0.318 & 0.071 & \\
\hline & Equity & 0.335 & & 0.205 & & 0.200 & 0.954 & 0.076 & 0.042 & 0.073 & 0.775 & 0.143 & \\
\hline
\end{tabular}

Notes: Each row represents the p-values from Granger causality tests. The exchange rate is differenced to ensure stationarity. 
Appendix Table 5 cont.

Granger causality tests of macroeconomic indicators of UK banking instability measured using standard deviation of returns.

\begin{tabular}{|c|c|c|c|c|c|c|c|c|c|c|c|c|c|}
\hline & \multirow{3}{*}{$\begin{array}{c}\text { Dependant } \\
\text { Variable } \\
\end{array}$} & & & & & & & & & & & & \\
\hline & & $\begin{array}{c}\text { Bank } \\
\text { Instability }\end{array}$ & $\begin{array}{c}\text { Risk } \\
\text { premium }\end{array}$ & $\begin{array}{c}\text { Equity } \\
\text { returns } \\
\text { (real, \%) }\end{array}$ & $\begin{array}{c}\text { Bank } \\
\text { lending } \\
\text { growth } \\
(\%)\end{array}$ & $\begin{array}{c}\text { GDP } \\
\text { growth } \\
\text { (real, \%) }\end{array}$ & $\begin{array}{c}\text { Money } \\
\text { supply } \\
\text { growth (\%) }\end{array}$ & $\begin{array}{c}\text { Inflation } \\
(\%)\end{array}$ & $\begin{array}{l}\text { Interest } \\
\text { rate } \\
\text { (real, \%) }\end{array}$ & $\begin{array}{l}\text { Exchange } \\
\text { Rate }\end{array}$ & $\begin{array}{l}\text { Public net } \\
\text { debt } \\
\text { growth } \\
(\%)\end{array}$ & $\begin{array}{c}\text { Wheat } \\
\text { price } \\
\text { growth } \\
(\%)\end{array}$ & $\begin{array}{l}\text { House } \\
\text { price } \\
\text { growth (\%) }\end{array}$ \\
\hline & & (p-value) & (p-value) & (p-value) & (p-value) & (p-value) & (p-value) & (p-value $)$ & (p-value) & (p-value) & (p-value) & (p-value $)$ & (p-value) \\
\hline \multirow{12}{*}{$\begin{array}{c}\text { Panel C: } 1901- \\
2010\end{array}$} & Bank Instability & 0.000 & 0.335 & 0.475 & 0.152 & 0.451 & 0.002 & 0.005 & 0.001 & 0.695 & 0.222 & 0.098 & 0.094 \\
\hline & Risk Premium & 0.455 & 0.000 & 0.739 & 0.330 & 0.721 & 0.333 & 0.373 & 0.390 & 0.932 & 0.613 & 0.083 & 0.259 \\
\hline & GDP & 0.002 & 0.494 & 0.217 & 0.833 & 0.010 & 0.020 & 0.060 & 0.159 & 0.831 & 0.094 & 0.174 & 0.085 \\
\hline & M3 & 0.928 & 0.444 & 0.235 & 0.002 & 0.002 & 0.000 & 0.258 & 0.189 & 0.058 & 0.051 & 0.313 & 0.508 \\
\hline & Inflation & 0.433 & 0.042 & 0.022 & 0.000 & 0.000 & 0.272 & 0.001 & 0.008 & 0.148 & 0.000 & 0.115 & 0.708 \\
\hline & Interest & 0.306 & 0.034 & 0.006 & 0.000 & 0.001 & 0.168 & 0.000 & 0.000 & 0.177 & 0.000 & 0.087 & 0.923 \\
\hline & Exchange Rate & 0.116 & 0.730 & 0.054 & 0.000 & 0.395 & 0.281 & 0.876 & 0.616 & 0.000 & 0.450 & 0.415 & 0.115 \\
\hline & Public Debt & 0.157 & 0.292 & 0.146 & 0.011 & 0.980 & 0.346 & 0.376 & 0.156 & 0.746 & 0.000 & 0.060 & 0.575 \\
\hline & Wheat Price & 0.009 & 0.388 & 0.505 & 0.304 & 0.219 & 0.434 & 0.130 & 0.002 & 0.324 & 0.156 & 0.043 & 0.148 \\
\hline & Equity & 0.178 & 0.049 & 0.025 & 0.001 & 0.019 & 0.910 & 0.164 & 0.062 & 0.422 & 0.050 & 0.109 & 0.184 \\
\hline & Lending & 0.032 & 0.040 & 0.678 & 0.750 & 0.078 & 0.066 & 0.412 & 0.300 & 0.002 & 0.101 & 0.315 & 0.530 \\
\hline & House Prices & 0.041 & 0.625 & 0.637 & 0.000 & 0.536 & 0.014 & 0.002 & 0.005 & 0.604 & 0.477 & 0.013 & 0.153 \\
\hline
\end{tabular}

Notes: Each row represents the p-values from Granger causality tests. The exchange rate is differenced to ensure stationarity. 